Portland State University

PDXScholar

$1-1-2002$

\title{
Integrated ecological economic modeling of the Patuxent River Watershed, Maryland
}

\author{
Robert Costanza \\ Portland State University \\ Alexey Voinov \\ University of Maryland \\ Roelof Boumans \\ University of Maryland \\ Thomas Maxwell \\ University of Maryland \\ Ferdinando Villa \\ University of Maryland
}

See next page for additional authors

Follow this and additional works at: https://pdxscholar.library.pdx.edu/iss_pub

Part of the Sustainability Commons

Let us know how access to this document benefits you.

\section{Citation Details}

Costanza et al. 2002. Integrated ecological economic modeling of the Patuxent River Watershed, Maryland. Ecological Monographs 72:203-231.

This Article is brought to you for free and open access. It has been accepted for inclusion in Institute for Sustainable Solutions Publications and Presentations by an authorized administrator of PDXScholar. Please contact us if we can make this document more accessible: pdxscholar@pdx.edu. 


\section{Authors}

Robert Costanza, Alexey Voinov, Roelof Boumans, Thomas Maxwell, Ferdinando Villa, Lisa Wainger, and Helena Voinov 


\title{
INTEGRATED ECOLOGICAL ECONOMIC MODELING OF THE PATUXENT RIVER WATERSHED, MARYLAND
}

\author{
Robert Costanza, $, 1,2,3,4$ Alexey Voinov, ${ }^{1,3}$ Roelof Boumans, ${ }^{1,3}$ Thomas Maxwell, ${ }^{1,3}$ \\ Ferdinando Villa, ${ }^{1,3}$ Lisa Wainger, ${ }^{3}$ and Helena Voinov ${ }^{1,3}$ \\ ${ }^{1}$ Institute for Ecological Economics, Center for Environmental Science, University of Maryland, Box 38, \\ Solomons, Maryland 20688-0038 USA \\ ${ }^{2}$ Biology Department, University of Maryland, College Park, Maryland 20742 USA \\ ${ }^{3}$ Chesapeake Biological Lab, Center for Environmental Science, University of Maryland, Box 38, \\ Solomons, Maryland 20688-0038 USA
}

\begin{abstract}
Understanding the way regional landscapes operate, evolve, and change is a key area of research for ecosystem science. It is also essential to support the "placebased" management approach being advocated by the U.S. Environmental Protection Agency and other management agencies. We developed a spatially explicit, process-based model of the $2352 \mathrm{~km}^{2}$ Patuxent River watershed in Maryland to integrate data and knowledge over several spatial, temporal, and complexity scales, and to serve as an aid to regional management. In particular, the model addresses the effects of both the magnitude and spatial patterns of human settlements and agricultural practices on hydrology, plant productivity, and nutrient cycling in the landscape. The spatial resolution is variable, with a maximum of $200 \times 200 \mathrm{~m}$ to allow adequate depiction of the pattern of ecosystems and human settlement on the landscape. The temporal resolution is different for various components of the model, ranging from hourly time steps in the hydrologic sector to yearly time steps in the economic land-use transition module.

We used a modular, multiscale approach to calibrate and test the model. Model results show good agreement with data for several components of the model at several scales. A range of scenarios with the calibrated model shows the implications of past and alternative future land-use patterns and policies. We analyzed 18 scenarios including: (1) historical land-use in 1650, 1850, 1950, 1972, 1990, and 1997; (2) a "buildout" scenario based on fully developing all the land currently zoned for development; (3) four future development patterns based on an empirical economic land-use conversion model; (4) agricultural "best management practices" that lower fertilizer application; (5) four "replacement" scenarios of land-use change to analyze the relative contributions of agriculture and urban land uses; and (6) two "clustering" scenarios with significantly more and less clustered residential development than the current pattern. Results indicate the complex nature of the landscape response and the need for spatially explicit modeling.
\end{abstract}

Key words: integrated ecological economic modeling; land use; landscape modeling; multiscale modeling; Patuxent River watershed, Maryland (USA); scaling; spatially explicit modeling; watersheds.

\section{INTRODUCTION}

Ecosystem scientists have long realized that the environment is being managed on scales too small to be effective and with goals that are too narrow (Odum 1971, Holling 1978, Gunderson et al. 1995). This is true for a broad range of questions and concerns, including global climate change, species conservation in old growth forests, and water quality in coastal ecosystems many miles below the source of pollutants. To be effective, attention needs to be focused on managing the health of large-scale ecosystems and landscapes, as well as integrating knowledge about ecosystems and economic systems across multiple scales (Costanza et al. 1992, Rapport et al. 1998). Often, these large eco-

Manuscript received 21 December 1999; revised 2 February 2001; accepted 29 March 2001; final version received 11 June 2001.

${ }^{4}$ E-mail: costza@cbl.umces.edu systems are most conveniently defined by drainage basins or watersheds. In addition, there is growing recognition that decisions about land use and management are usually made with little attention paid to their ecological impacts, and these impacts are significant at several scales, from the local to the global (Dale et al. 2000).

Partly as a result of these insights and a concerted effort by ecosystem scientists, there has been a major movement over the last decade toward place-based, ecosystem-based, and watershed-based management. For example, the United States Environmental Protection Agency's (US EPA) Office of Research and Development (ORD) states the following:

The Agency has placed increased emphasis on community and place-based approaches to environmental management. These efforts represent a fundamental change from traditional single media-based ap- 
proaches for environmental regulation to a concern for the impact of multiple stressors over a broad range of spatial scales. [The Office of Research and Development] needs to provide communities the processes and tools that communities are able and willing to use to determine what ecological resources are at risk and how best to protect those resources through management action.

-US EPA ${ }^{5}$

As a result of this shift, there are now many programs aimed at watershed-scale ecosystem management, including: the Great Lakes Program, ${ }^{6}$ the Chesapeake Bay Program, ${ }^{7}$ and the National Estuary Program. ${ }^{8}$ The State of Maryland now has significant experience with watershed-based approaches to water quality protection and restoration. This has come about largely as a part of the multistate federal Chesapeake Bay Program and because the water quality of downstream tidal and estuarine waters has been recognized to be heavily influenced by upstream sources, particularly nonpoint sources. In addition, the nature of the Maryland portion of the Bay watershed lends itself to delineation of discrete tributary watersheds that include tidal rivers. A major focus of the program to restore the water quality of the Bay involves a "tributary strategy," in which the sources of pollutants are estimated for each tributary watershed, fluxes are modeled, loadings are related to ecological conditions and living resources in the receiving subestuary, and goals are set for reduction of contaminants by generating sector (e.g., sewage treatment plants, agriculture, and dispersed residential) and location in the watershed. The Patuxent is one of the most important of these tributaries, and a wealth of data has been collected within and near the river, as we will describe.

To support this effort to effectively manage the complex interactions between human and natural systems at the watershed scale, integrated (across scales and across disciplines) scientific and technical knowledge and models are needed. We need to develop a better predictive understanding of ecosystem processes and properties over large watersheds, including the processes and mechanisms that govern the interconnected dynamics of water, nutrients, toxins, and biotic components and their linkages to human factors affecting water and watersheds, in particular land cover, land use, and management.

We have developed an integrated modeling framework aimed at addressing these goals. The approach evolved from work in coastal Louisiana (Costanza et al. 1990) and in the Everglades (Fitz et al. 1993). Current work is focused on the Patuxent River watershed

\footnotetext{
${ }^{5}$ URL: 〈http://www.epa.gov/nceawww1/weracs.htm〉

${ }^{6}$ URL: 〈http://www.epa.gov/glnpo〉

${ }^{7}$ URL: 〈http://www.chesapeakebay.net〉

${ }^{8}$ URL: 〈http://www.epa.gov/nep〉
}

in Maryland (Fig. 1), one of the best-studied tributaries of the Chesapeake Bay, and one that has often been used as a model of the entire Bay system.

Land-use manipulation by humans began in the $\mathrm{Pa}$ tuxent watershed before European colonists first settled in the Chesapeake Bay. Native Americans burned the forest, removing underbrush and promoting growth of large trees (K. Mountford, unpublished manuscript). However, the sediment record in the Bay and its tributaries only begins to show the influences of land-use change after European settlement in the 17th century (Brush and Davis 1984, Cooper 1995). It was not until massive land clearing and new farming practices were implemented in the 18 th century that ecological effects became significant in the river and estuary. Mountford (unpublished manuscript) has tracked the changes in land use and management in the basin and outlines the beginnings of many of the modern-day concerns in the Chesapeake Bay. He describes a growing colonist population that rose from a nominal 150 persons in 1640 to 250000 in 1776 , and whose activities increasingly impacted the river ecosystems. Colonist farming practices, such as allowing livestock to range free, led to the local extinction of some herbaceous plants. Soil erosion increased dramatically, as turning the soil before planting became a common practice in the 18th century, and tillage straight downhill was used to assist animal plowing. Agriculture spread first from the coastal plain then up into the piedmont in the 1700 s. Census data indicates that by $1840,40-50 \%$ of the land in Southern Maryland had been deforested (Brush and Davis 1984). As massive amounts of land were cleared, the estuary underwent major changes in sedimentation, eutrophication, and hydrologic regimes. Sediment studies in a freshwater marsh (Jug Bay) in the Patuxent show that sedimentation rates have gone from 0.05 $0.08 \mathrm{~cm} / \mathrm{yr}$ before European settlement to $0.50 \mathrm{~cm} / \mathrm{yr}$ on average in the mid-1800s, the time of maximum land clearance (Khan and Brush 1994). Between the 1750s and 1770s, Upper Marlboro in the mid to upper Patuxent became too shallow to be used as a port (K. Mountford, unpublished manuscript). During this time, low marsh was being replaced by high marsh, and open water was replaced by low marsh in the mid-Patuxent (Khan and Brush 1994). Sedimentation increased again in the late 1890 s to early 1900 s. Cores from the Khan and Brush study show sharp increases in sedimentation rates in the mid-1960s through the mid-1970s and again in early 1980 s when rapid urbanization occurred in the upstream watershed. Rates have decreased somewhat since then, but current water depth at Jug Bay is only approximately one meter according to their study.

Evidence for increasing eutrophication following European settlement is strong in the sediment record in the oligotrophic part of the Patuxent (Brush and Davis 1984, Cooper 1995), with biogenic silica, diatom diversity and changes in relative abundance of certain species of diatoms all indicating eutrophication and 


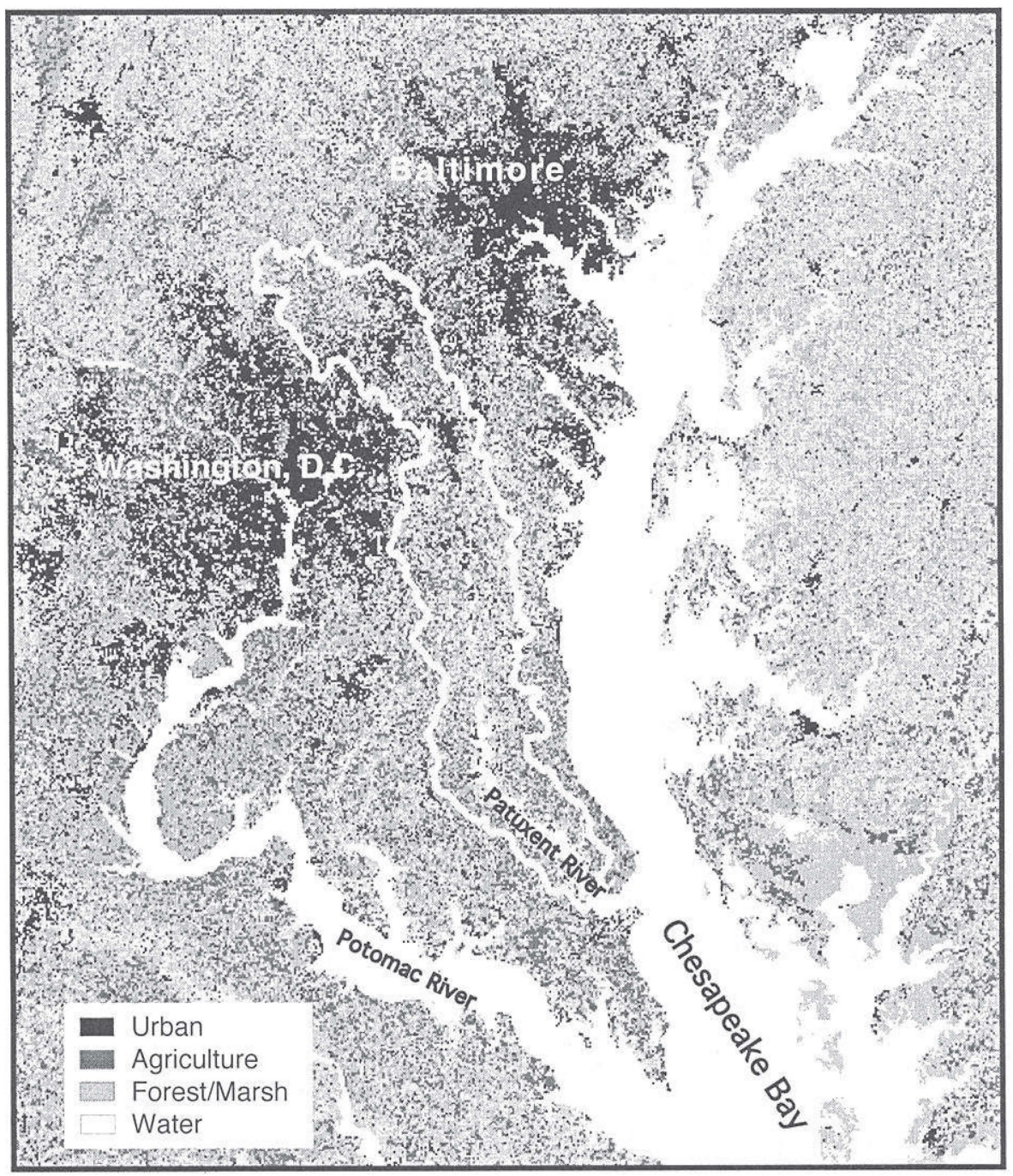

FIG. 1. Location of the Patuxent watershed. The background map is based on National Oceanic and Atmospheric Administration Coastal Change Analysis Program land cover data of Chesapeake Bay Watershed 1988-1989. The resolution is $30 \mathrm{~m}$.

some cores showing peaks in eutrophication indicators at the time of initial land clearance for agriculture $(\sim 1760 \mathrm{AD})$. Concentrations of organic carbon, nitrogen, and sulfur also show marked increases after this point (Cooper 1995). Diatom species show a strong shift at the time that fertilizers were introduced in 1860 , and sewage inputs to the river led to increases in total diatom abundance. The mesohaline portions of the lower Patuxent show much less dramatic changes over time than the oligotrophic sites, although sedimentation increases and diatom species shifts are evident (Brush and Davis 1984). Submerged aquatic vegetation (SAV) decreased dramatically in the mid-1960s, coincident with the growing use of herbicides. However, herbicides were largely exonerated as the cause of the macrophyte decline, which was instead attributed to eutrophication and sedimentation (Kemp et al. 1983, 1985). Aerial photos from 1938 show large SAV beds in the
Patuxent, some extending $300 \mathrm{~m}$ offshore (K. Mountford, unpublished manuscript). The grasses have recently begun to reappear in significant amounts in some northern parts of the river, beginning in 1994 (Orth et al. 1995) (see also Virginia Institute of Marine Science Submerged Aquatic Vegetation Mapping Lab 1997). ${ }^{9}$ The changing land use has somewhat competing effects on the hydrologic regime. Removal of trees tends to reduce the evapotranspiration rates, leading to potentially higher freshwater inflows to the stream. Data from Baltimore Harbor in the Patapsco River just north of the Patuxent River (Fig. 1) suggest salinity has decreased in the last 500 years, which supports this idea (Biggs 1981). Yet, the effects of increased impervious surfaces can lead to decreased stream base flows by

${ }^{9}$ URL: 〈http://www.vims.edu/bio/sav/index.html〉 
preventing groundwater recharge, although storm peak flows would be expected to increase.

Current land-use practices in the basin are the subject of intense scrutiny as planners and legislators search for ways to limit the impact of human population growth on natural resources. In 1994, $\sim 50 \%$ of the watershed remained in natural vegetation ( $40 \%$ forest), and the developed land uses included $15 \%$ residential, $5 \%$ commercial/industrial, and $30 \%$ agriculture (Fig. 2 ). The seven counties that encompass the watershed are experiencing some of the highest growth rates in the state. The rate of forest loss during 1985-1990 was $>2400$ ha in the majority of the counties, and agricultural land declined over the same period by $>800-$ 1600 ha in most counties (Maryland Office of Planning 1993).

\section{METHODS}

Two problems arise from the heterogeneity among watersheds that present major challenges to both research and management. First, variation in structure and function inevitably prevents true replication in intensive field studies that attempt to relate landscape function to landscape structure. Second, variation among land uses within watersheds makes it difficult to directly extrapolate intensive studies to larger spatial scales. Even though drainage basins can be broken down hierarchically into smaller catchments based on topography, "scaling up" from intensive catchment studies is not a linear additive process because of differences among catchments and interactions between adjacent land uses. Management of water quality over large drainage basins must address both problems with innovative methods synthesizing data from intensive experimental studies on a few watersheds, then extrapolating important generalizations to large drainages using appropriate modeling techniques. Spatially explicit process-based modeling is one approach to understanding nutrient flux from heterogeneous watersheds (Costanza et al. 1990, Sklar and Costanza 1991). These models can incorporate understanding of the physical and ecological processes that either retain or release nutrients in watersheds by (1) identification of ecological or anthropogenic processes important in making labile nutrients available for export, (2) simulation of hydrologic flow paths as potential "routes" of nutrient export, and (3) linking spatial patterns of labile nutrient concentrations with water flow paths. By focusing on processes, this approach gains potential generality of application at different spatial scales and at new locations. General process models require intensive data for development and independent data for testing. Thus these models are best developed from intensive empirical and model calibration studies of contrasting subwatersheds at several scales and tested by their ability to predict water and nutrient export from a variety of watersheds.

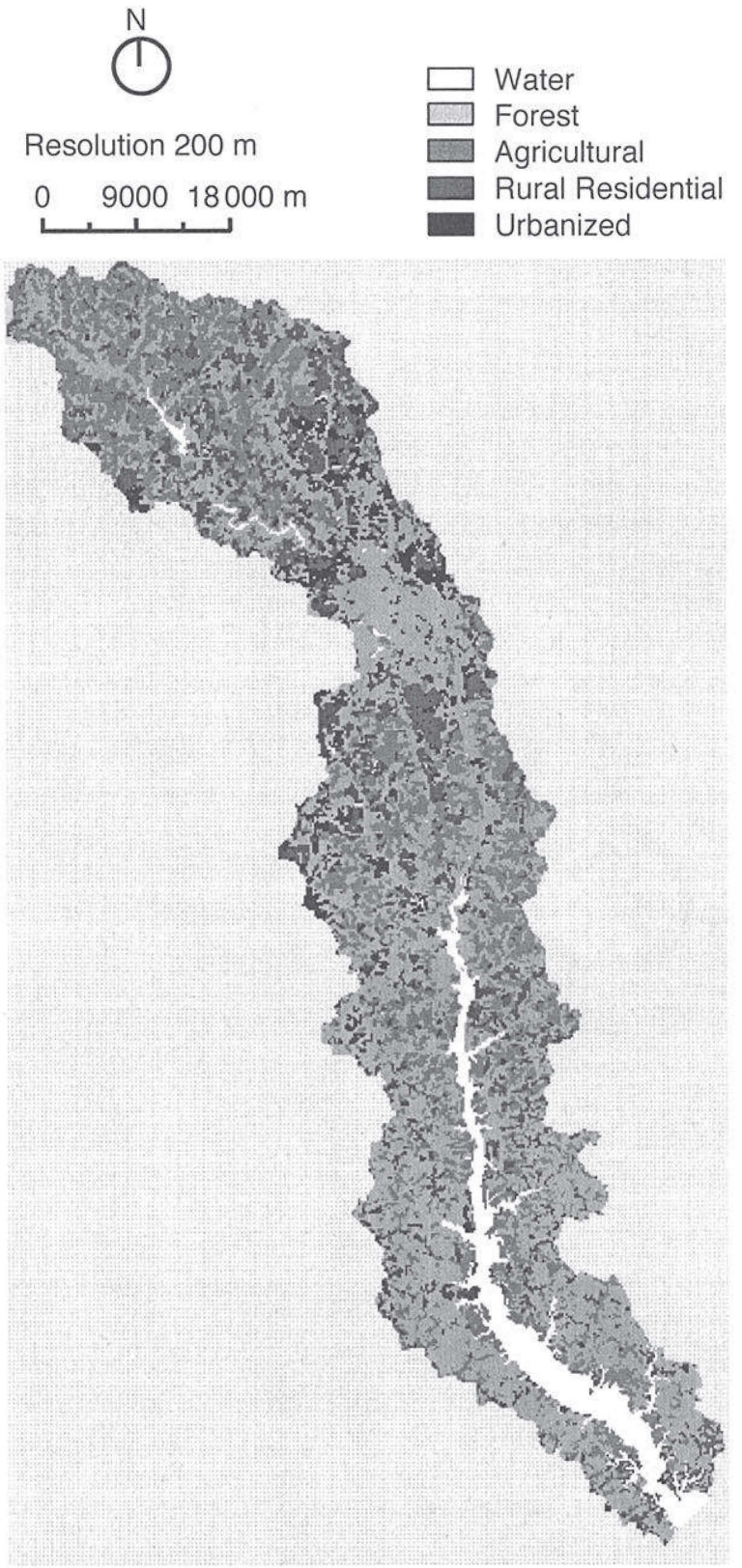

FIG. 2. Patuxent watershed land-use map for 1994 , based on the Maryland Counties Generalized Land Use/Land Cover maps acquired from the Maryland Office of Planning. The label "urbanized" includes high-density residential, commercial, and industrial uses.

\section{The Patuxent landscape model (PLM)}

The Patuxent landscape model (PLM) is a spatially explicit, multiscale, process-based model designed to serve as a tool in a systematic analysis of the interactions among the physical and biological dynamics of the watershed, conditioned on socioeconomic behavior in the region. A companion socioeconomic model of the region's land-use dynamics was developed to link 


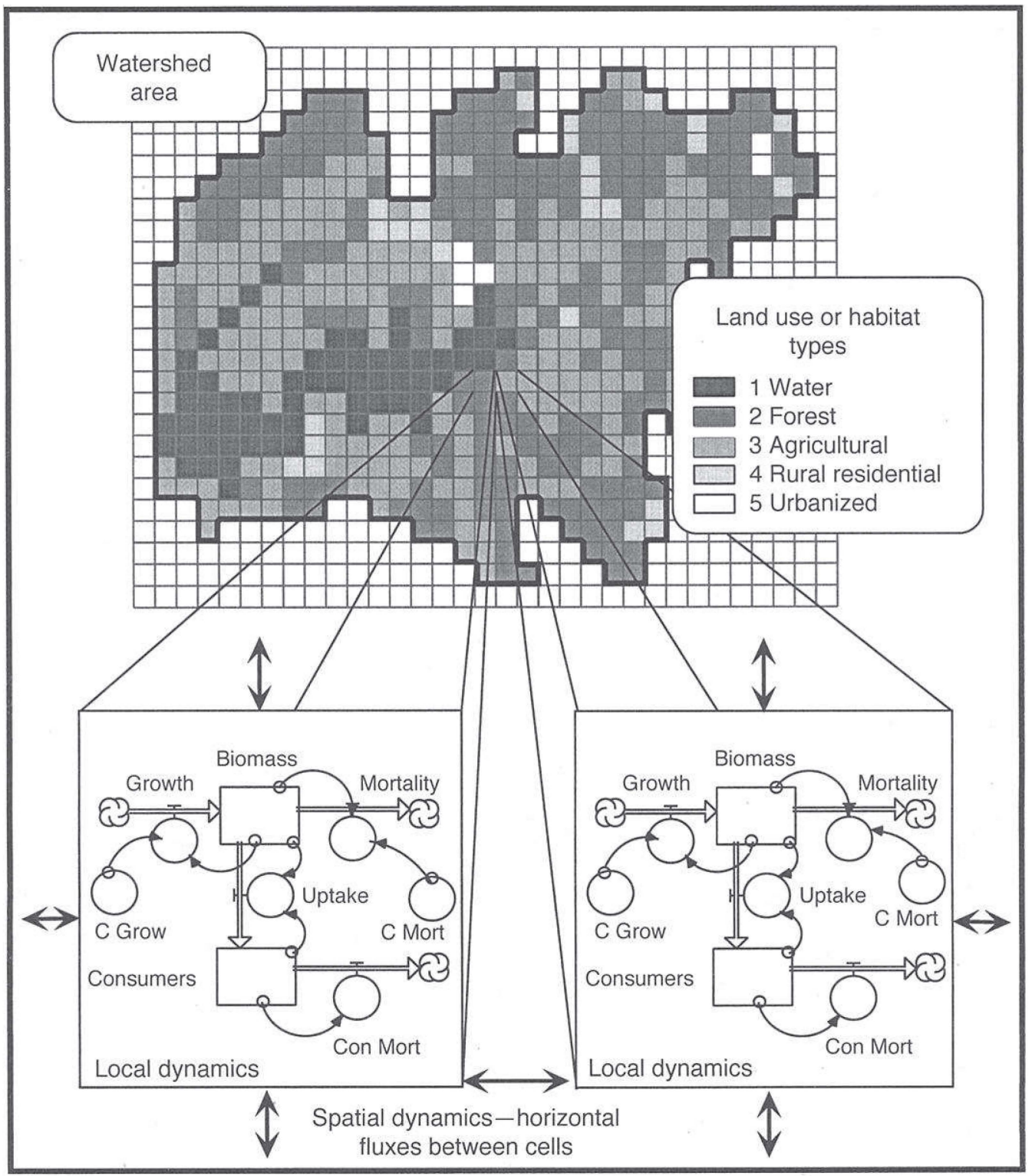

FIG. 3. The cellular structure of the Patuxent landscape model (PLM) presented in the format of a STELLA model replicated in each of the cells. Each cell has a (variable) habitat type, which is used to parameterize the unit model for that cell. The unit model simulates ecosystem dynamics for that cell in the above-sediment and below-sediment subsystems. Nutrients and suspended materials in the surface water and saturated sediment water are fluxed between cells in the domain of the spatial model. Cell sizes vary $30 \mathrm{~m}-1 \mathrm{~km}$ in different model implementations.

with the PLM and provide a means of capturing the feedbacks between ecological and economic systems.

In the ecological component of the model, the important processes that affect plant communities are simulated within the varying habitats distributed over the landscape. The principal dynamics modeled are as follows: (1) plant growth in response to available sunlight, temperature, nutrients, and water; (2) flow of water plus dissolved nutrients in three dimensions as mediated by soils, evapotranspiration, topography, and nutrient uptake and release; (3) decomposition of dead organic material and formation of soil organics. Using this ap- proach to incorporating process-based data at a reasonably high spatial, temporal, and complexity resolution within the entire watershed, the changing spatial patterns and processes can be analyzed within the context of altered management strategies, such as the use of agricultural best management practices (BMPs) (e.g., reduced fertilizer application and reduced tillage).

The modeled landscape is partitioned into a spatial grid (ranging in this application within 2352-58905 square unit cells). The model is hierarchical in structure, incorporating an ecosystem-level "unit" model 
that is replicated in each of the unit cells representing the landscape (Fig. 3). The unit model, referred to as the general ecosystem model (GEM; Fitz et al. 1996), itself is divided into submodels or modules representing functional divisions that simulate the important dynamics for each aspect of the system.

The current GEM unit model includes modules for hydrology, nutrients, plants, consumers, and humandominated systems. The hydrology module of the unit model is a fundamental component for other modeled processes, simulating water flow vertically within the cell. Phosphorus and nitrogen are cycled through plant uptake and organic matter decomposition. The plant module includes growth response to various environmental constraints (including water and nutrient availability), changes in leaf canopy structure (influencing water transpiration), mortality, and other basic plant dynamics. Feedbacks among the biological, chemical, and physical model components are important structural attributes of the model. While the unit model simulates ecological processes within a unit cell, horizontal fluxes link the cells together across the landscape to form the full PLM. Such fluxes are driven by cell-tocell head differences of surface and ground water in saturated storage. Within this spatial context, the water fluxes between cells carry dissolved and suspended materials, determining water quality in the landscape.

The same general unit model structure runs in each cell. Individual cells are parameterized according to habitat type (i.e., forest, grassland, agriculture, urban) and georeferenced information for each cell stored in geographic information systems (GIS) files. A habitatdependent parameter database includes initial conditions, rate parameters, stoichiometric ratios, etc. The parameter set used in each cell (reflecting the vegetation community type and other conditions) responds to changing hydrologic and nutrient regimes via successional switching algorithms that determine when local conditions favor a different habitat (Costanza et al. 1990). For example, if water levels increase sufficiently in a cell, it might change from forest to open water and the parameter set would change accordingly. Thus, when run within the spatial framework of the PLM, the landscape pattern responds to changing hydrology and water quality as simulated by material flows between adjacent cells.

The ecological model is linked to a companion economic model that predicts the probability of land use change within the seven counties of the Patuxent watershed (Bockstael 1996). The economic model allows human decisions to be modeled as a function of both economic and ecological spatial variables. Based on empirically estimated parameters, spatially heterogeneous probabilities of land conversion are predicted as functions of land values in residential and alternative uses, as well as costs of conversion. Land value predictions, themselves, are modeled as functions of local and regional characteristics. The model of land-use conversion generates the relative likelihood of conversion of cells, and thus the spatial pattern of greatest development pressure. To predict the absolute amount of new residential development, the probabilistic landuse conversion model is combined with models of regional growth pressure. Linking the ecological and economic models allows the effects of both direct landuse change through human actions and indirect effects through ecological change to be evaluated, as well as the feedbacks between the two.

\section{Comparison with other ecosystem "unit" models}

The GEM is one of several site-specific ecological models that are process based and are designed to apply to a range of habitats. Some other models within this category are CENTURY (Parton et al. 1988), terrestrial ecosystem model (TEM; Vorosmarty et al. 1989), and biome-biogeochemical cycles (BIOME-BGC; Running and Coughlan 1988). All of these models can be adapted to a particular site through parameterization of initial stocks and flux rates among various ecosystem components. General habitat models are suitable for building landscape models through spatially referenced parameterization of a spatial grid of cells that represent the various ecosystems composing a landscape (Costanza et al. 1990, Maxwell and Costanza 1994, Creed et al. 1996). See Fitz et al. (1996) for a comparison of the GEM/PLM model with other hydrologic and landscape models.

Among available ecosystem models, there is a large variation in complexity and capabilities. Often it is this variation that makes one model more suitable for certain applications than others. As a rule of thumb, more complex models will resolve issues in more detail, but are more difficult and time-consuming to calibrate and run, and beyond a certain complexity may, in fact, provide decreasing predictability (Costanza and Maxwell 1994).

Some landscape models include horizontal fluxes and exchange across cells, while others do not. Often these horizontal fluxes are controlled by a hydrological model. In addition to water, other possible horizontal fluxes include movement of air, animals, and energy, such as fire and water waves. The least complex interaction between horizontal and vertical fluxes is unidirectional, where horizontal fluxes provide the conditions to calculate vertical fluxes. A more complex approach would include bidirectional exchanges of information between the horizontal and vertical fluxes.

An example of a landscape model that does not include horizontal fluxes between cells uses the TEM unit model (Vorosmarty et al. 1989) and a water transport model based on residence time to remove excess water from each cell. Creed et al. (1996) created a landscape model with unidirectional information exchange by applying the regional hydro-ecological simulation system (RHESSys) for hydrologic exchanges and BIOME$\mathrm{BGC}$ for vertical fluxes. Multidirectional exchanges are 
used in PLM and CENTURY to move water and materials between landscape cells (Voinov et al. 1999a, Parton et al. 1992).

Computational capabilities, research objectives, and data availability determine the optimum complexity and modes of information exchange between horizontal and vertical fluxes. In general, simulations with large spatial and temporal extents (e.g., global scenarios run at monthly or yearly time steps with a total time frame of centuries) perform best at lower complexities and with no horizontal fluxes. Simulations at smaller time steps and higher spatial resolution (e.g., regional models at daily or hourly time steps run for decades) often allow a more complex structure and multidirectional exchange potential.

The GEM/PLM aims for an intermediate level of complexity, so that the model is flexible enough to be applied to a range of ecosystems but is not so cumbersome that it requires a supercomputer. Although we take into account most important ecological processes, there is still a good deal of empiricism in the way these processes are formalized. The model represents a balance between the process-based paradigm and empirical relationships in the description of individual processes (Voinov et al. 1998). This limits the generality of the model, potentially requiring additional testing and calibration when switching to other scales or areas. However, it allows us to keep the whole model within reasonable limits of complexity. In addition, the modular structure allows users to streamline the model and reduce the full complexity by applying only those modules that are relevant to their simulation objectives.

\section{Geographic and time series data}

A variety of spatially and temporally disaggregated data is required to develop and calibrate the model. The database we have assembled is partially described in the Appendix. The model database contains the data that drive the model forcing functions, parameterize equations, and provide calibration and verification data for adjusting model parameters and comparing model output to the real system. The database was developed from extensive data sets collected for the Patuxent watershed by various governmental agencies, academic institutions (see the Appendix), and research programs (Correll 1983, Brush et al. 1980, Peterjohn and Correll 1984, Correll et al. 1992, Lichtenberg and Shapiro 1997). Existing data for the local region were supplemented with broader regional databases where appropriate.

Much of the available data is at a temporal or spatial resolution that is different than we would like, so we sometimes employed data aggregation or interpolation techniques to adjust the data. For example, maps of model driving forces such as precipitation are created as the model runs by interpolating time series data from the set of seven meteorological stations distributed throughout the area. Land-use data are aggregated from higher resolution maps with more categories than we need. Another example is our use of elevation data (1: 100000 , with $1-\mathrm{m}$ vertical resolution) combined with river network data (Maryland Office of Planning 1993) to improve the watershed boundary and shoreline delineation.

Spatial (GIS) data include several types of data sets. One set of maps describes initial conditions, such as land cover, elevation, soil type, bathymetry, and groundwater elevation. Other spatial data developed from satellite images provide a time series of estimated ecological conditions that are used for calibration purposes (e.g., normalized-difference vegetation index [NDVI]; Kidwell 1986; J. Jones, personal communication). Watershed boundary, slope, aspect, and study area map layers were developed with the watershed basin analysis program in the Geographic Resources Analysis Support System (GRASS; U.S. Army Construction Engineering Research Laboratories 1993). Fig. 4 shows the basic spatial coverages that have been employed in the PLM and some of the derived layers that were also essential for the hydrologic module. Spatial fluxes of surface water in watershed models are predominantly driven by the elevation gradient.

In addition to the meteorological time series data that are used to map daily weather conditions, time series data are used to provide other information at specific points in the landscape. For example, point source discharges are used to introduce materials at specific points in the landscape. Hydrologic point time series data (stream flow, surface, and ground water quality) are used for calibration in the nontidal portions of the streams.

Specific rate constants are generally functions of spatial or habitat characteristics, such as soil or vegetation type. Habitat-dependent parameters include growth coefficients, uptake rates, and seasonal controls. About half of these data are specific to the Patuxent watershed, with the remainder derived from a more general database or from literature sources.

\section{Unit model}

The general ecosystem model (GEM), which was developed for the Everglades landscape model (ELM) ${ }^{10}$ (Fitz et al. 1996), was modified for use within the framework of the PLM. The model was reformulated on a modular basis, with each module capable of being run and calibrated independently (Voinov et al. 1999a). The independent modules and the full unit model have also been run in the spatial implementation and rigorously tested at the full watershed scale. The GEM components that have been modified the most are described here. For further details about these or other modules (phytoplankton, dead organic material, etc.)

${ }^{10}$ URL: 〈http://www.sfwmd.gov/org/erd/esr/elm.html〉 


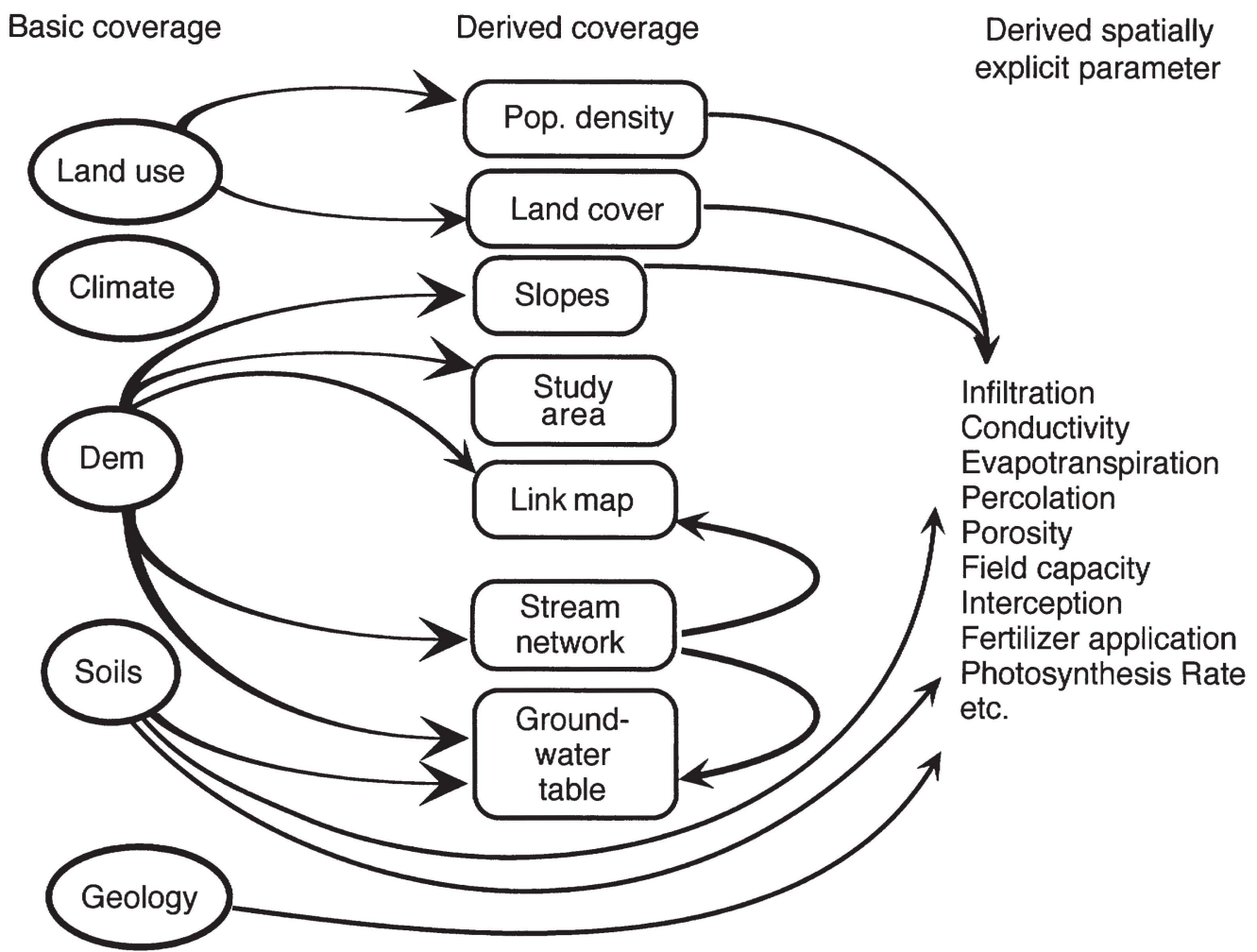

FIG. 4. Patuxent landscape model (PLM) spatial coverages. There are six basic coverages: land use, climate, digital elevation model (DEM), soils, and geology. The arrows connect basic coverages with derived coverages. Additional maps are created during preprocessing and model initialization. Other spatial parameters and variables are calculated and updated during model runs.

the reader is referred to the paper by Fitz et al. (1996) and to the Library of Hydro-ecological Modules. ${ }^{11}$

Sensitivity analysis was used to gain insight about the model dynamics, showing the varying response of plant production to different nutrient requirements, with subsequent changes in the soil water nutrient concentrations and total water head. Changes in the plant canopy structure resulted in differences in transpiration, and consequently water levels and plant production.

\section{Hydrology module}

The hydrologic module simulates vertical water fluxes for a locality that is assumed to have spatially homogeneous characteristics. The module takes into account a variety of hydrologic functions controlled by physical and biotic processes including the following:

1) Vertical water movement between surface, unsaturated and saturated storage from percolation, aquiferstream interactions, and evapotranspiration.

2) Spatial climatic forcing based on rainfall, temperature, humidity, and wind condition data.

3) Transpiration fluxes dependent on plant growth, vegetation type, and relative humidity.

The traditional scheme of vertical water movement

${ }^{11}$ URL: 〈http://iee.umces.edu/LHEM〉
(Novotny and Olem 1994), also implemented in GEM, assumes that water is fluxed along the following pathway: rainfall, surface water, water in the unsaturated layer, and finally water in the saturated zone. In each of the stages, some portion of the water is diverted due to physical (evaporation, runoff) and biological (transpiration) processes, but in the vertical dimension the flow is controlled by the exchange between these four major phases.

At a daily time step, the model does not attempt to mimic the behavior of shorter-term events such as the wetting front during an infiltration event. During a rapid rainfall event, surface water may áccumulate in pools and litterfall, but in a catchment such as the Patuxent, over the period of a day, most of this water will either infiltrate, evaporate, or be removed by horizontal runoff. Infiltration rates based on soil type within the $\mathrm{Pa}$ tuxent watershed range $0.1-10 \mathrm{~m} / \mathrm{d}$, generally accommodating all but the most intense rainfall events in vegetated areas. The intensity of rainfall events can strongly influence runoff generation, but climatic data are rarely available for shorter than daily time steps. Also, if the model is intended to be run over large areas for many years, the diel rainfall data become inappropriate and difficult to project for scenario runs. Therefore, a certain amount of temporal detail must be forfeited to facilitate regional model implementation. 
Fig. 5. The unit hydrological model. The state variables are surface water, snow/ice, unsaturated water, and saturated water. The major processes are precipitation, evapotranspiration, infiltration, and percolation.

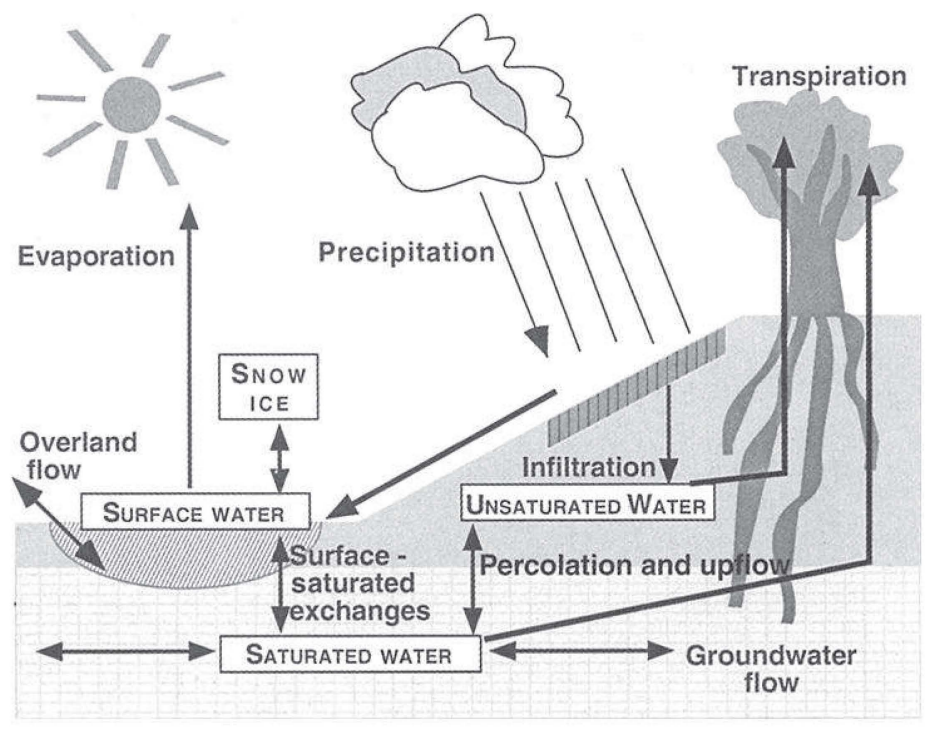

With these limitations in mind, we have simplified the unit hydrologic model (Fig. 5):

1) We assume that rainfall infiltrates immediately to the unsaturated layer and only accumulates as surface water if the unsaturated layer becomes saturated or if the daily infiltration rate is exceeded. Ice and snow may still accumulate.

2) Surface water may be present in cells as rivers, creeks, and ponds. Surface water is removed by horizontal runoff or evaporation.

3) Within the one-day time step, surface water flux will also account for the shallow subsurface fluxes that rapidly bring the water distributed over the landscape into the microchannels and eventually to the river. Thus, the surface water transport takes into account the shallow subsurface flow that may occur during rainfall, allowing the model to account for the significantly different nutrient transport capabilities between shallow and deep subsurface flow.

\section{Nutrient module}

Nutrient enrichment is arguably the most important environmental degradation factor within the Patuxent watershed, especially in the estuary. The PLM's process-based algorithms are designed to track the quantities of labile forms of phosphorous and nitrogen through the landscape during a simulation. Only phosphorous and nitrogen are tracked, as they are the most likely nutrients to limit plant growth rates. Nutrient inputs of anthropogenic origin respond to socioeconomic forces, and the effects of these inputs can be observed in plant production within the various habitats.

The original GEM nutrient sector was adapted to better match the aggregated hydrologic module. Various nitrogen forms, $\mathrm{NO}_{2}^{-}, \mathrm{NO}_{3}{ }^{-}$, and $\mathrm{NH}_{4}{ }^{+}$were aggregated into one variable representing all forms of nitrogen that are directly available for plant uptake.
Available inorganic phosphorus is simulated as orthophosphate. The distinction appears in conceptualizing nutrients on the surface, since in the PLM they are no longer associated with surface water and therefore need not be in the dissolved form. Instead, since most of the time most of the cells have no surface water, the model variables represent the dry deposition of nitrogen or phosphorus on the surface. Over dry periods they continue to accumulate nutrients from incoming fluxes from air deposition or mineralization of organic material. When rainfall occurs, a certain proportion of the accumulated nutrients become dissolved and made available for horizontal fluxing and infiltration.

Further modification of the nutrient dynamics were required to accommodate the aggregation of surface and shallow subsurface flows in the hydrologic sector. In the PLM a fraction of the nitrogen and phosphorus stored in the upper soil layer is made available for fast horizontal fluxing along with nutrients on the land surface. We have assumed this layer to be $10 \mathrm{~cm}$ thick, following a similar formalization in the carbon-nitrogen-sulfer (CNS) model (Haith et al. 1984), where this upper soil layer was also assumed to be exposed to direct surface runoff.

In addition to atmospheric deposition, the nutrient sources include sewage discharges, fertilizer applications and discharges from septic systems. At present, nutrient storage in biomass is estimated from empirical data on 12 U.S. east coast mixed-forest plots (Johnson and Lindberg 1992). Dissolved inorganic nutrients are removed from the system through the growth of biomass and released through mineralization of soil or suspended organics. Nutrient uptake and release are modeled as proportional to total net primary productivity and decay at rates estimated from elemental carbon ratios measured in similar ecosystems. 


\section{Plant module}

In the plant module we simulate the growth of higher vegetation. This will be macrophytes in an aquatic environment, trees in forests, crops in agricultural habitats, and grasses and shrubs in grasslands. The plant biomass (measured in kilograms per square meter) is assumed to consist of photosynthesizing ( $\mathrm{PH}$ ) and nonphotosynthesizing (NPH) components. In addition, we distinguish between aboveground and belowground biomass and production.

Another state variable is employed to track "biological time" in the module. Biological time is the sum over the life span of the plant of the amount of time during which daily average temperatures exceed a certain value $\left(5^{\circ} \mathrm{C}\right.$ in our case). This is the temperature regime that is most suitable for the physiological development of the plant. Therefore the total time during which such temperatures occur is a good indicator of the plant life stage and may be used to trigger certain processes such as sprouting, appearance of reproductive organs, etc.

The plant sector models conversion of inorganic carbon and nutrients into specific forms of biomass and provides linkages to the hydrology through evapotranspiration. It includes both photosynthetic and nonphotosynthetic biomass components. Maximum uptake rates are derived from empirical data relative to seasonal temperatures. During the simulation, maximum uptake rates are limited by light, nutrient concentrations, and water availability. The resultant uptake quantity is derived by multiplying the resultant uptake rate by the total photosynthetic potential (total leaf area).

The maximum attainable leaf area is habitat specific and is derived empirically as a proportion of the total biomass. Biomass and nutrients are accounted for in both above- and belowground material. Once the optimum leaf-to-biomass ratio is reached during plant growth, excess biomass is routed to the nonphotosynthetic component. The increase of total biomass allows additional increases in photosynthetic biomass. The nonphotosynthetic biomass feeds back into the photosynthetic part by means of early spring sap flows in deciduous trees and through seed germination.

Plant mortality provides an input to detrital matter. Depending on the lignin content, we distinguish between stable and labile detritus. Stable detritus is shredded and becomes soil organic material or labile detritus. Both soil organics and labile detritus are further decomposed to produce nutrients available for plant uptake.

\section{Human-dominated systems}

Nutrients generated by human activities are of particular concern in the Patuxent River watershed because as a Chesapeake Bay tributary it has been targeted for a $40 \%$ reduction in nutrient input levels. Agricultural and urban land-use management constitute the focus of efforts to reduce nonpoint source nutrient inputs to water bodies throughout the Chesapeake Bay watershed. Research indicates that relatively simple, low-cost methods of farm nutrient management could have a significant impact on surface and ground water quality in the United States (Correll 1983, Crum et al. 1990, Lynch and Corbett 1990, Magette et al. 1990; L. Shabman, unpublished manuscript), but the effects at the landscape scale of changing farming practices are not known.

The PLM can directly analyze changing land management practices for their effect on nutrients, water budgets, and plant ecosystems. Agricultural and urban practices that influence nutrient loading and water flow rates are expressed in the variables that influence infiltration rates, as well as sinks and sources of nutrients. Agriculture is modeled using the plant sector of the model with special variables to account for fertilizer application and harvest times. To overcome the lack of spatially explicit data on farming practices, we used rates that are specific to soil type and county, and we rely on general information from those working with farmers and assessing nutrient practices in the basin. Since nutrient application rates are related to crop yields, and since yield estimates vary by soil, we were able to estimate application rates for each parcel of farmland identified in the land-use map by linking recommended nutrient application rates (Bandel and Heger 1994) to maps of soil and county. We plan to further refine the estimates of fertilizer application rates using the available data on county-level farming practices such as proportions of crops grown, rotation patterns, tillage types, and manure use. Currently we assume a crop rotation that is standard for this area. It includes corn, winter wheat, and soybeans over a two-year time period.

Urbanization effects are largely handled through land cover-dependent parameters for the hydrology and nutrient modules of the GEM unit model. Available information on urban nutrient sources such as road runoff and septic tank discharges are linked to existing GIS layers such as locations of roads and unsewered residential development to estimate the spatial distribution of these inputs. Point source discharge information, available in the form of time series data, is input to the appropriate cells in the PLM. Information on distribution and effectiveness of storm water management is used to parameterize residential land cover cells. The spatial model accounts for the effects of flow path on nutrient movement. As nutrient-containing water moves from urban to undeveloped cells, nutrients in surface water can be removed. Parameters on the type of soil, slope, and vegetation present in a cell determine whether that cell acts as a net source or sink for nutrients.

\section{Spatial model}

The spatial model combines the dynamics of the unit model (which are calculated at each time step for each 
cell in the landscape) and adds the spatial fluxes that control the movement of water and materials between cells. Each cell generates stock and flow values that provide input to or accept output from the spatial flux equations.

In the spatial implementation, a major hypothesis tested is that overland and channel flow can be modeled similarly. Traditionally, in most models of overland flow the surface water is moved according to two separate algorithms: one for the two-dimensional flux across the landscape and another for the one-dimensional channel flow. This approach is used in some of the classic spatial hydrologic models such as the areal nonpoint source watershed environment response simulation (ANSWERS) (Beasley and Huggins 1980) or systeme hydrologique Europeen (SHE) (Abbott et al. 1986). However, considering the spatial and temporal scale of the Patuxent model, as well as its overall complexity, we use a simplified water balance algorithm for both types of flow.

Given the cell size of the model $(200 \times 200 \mathrm{~m}$ or 1 $\mathrm{km}^{2}$ ), we may assume that in every cell there will be a stream or depression present where surface water can accumulate. Therefore it makes sense to consider the whole area as a linked network of channels, where each cell contains a channel reach that discharges into a single adjacent channel reach. The channel network is generated from a link map that connects each cell with its one downstream neighbor, out of the eight possible nearest neighbors. Riparian vegetation affects the results by modifying surface and ground water flow in the stream cells and downstream cells; this is reflected in the model parameters. In the GEM unit model vegetation and nutrients are closely linked with hydrology through evapotranspiration and other processes.

After the water head in each raster cell is modified by the vertical fluxes controlled in the GEM unit model, the surface water and its dissolved or suspended components move between cells based on one of two algorithms being tested. In the simplified algorithm, a certain fraction of water is taken out of a cell and added to a cell downstream. This operation is either iterated several (10-20) times a day, effectively generating a smaller time step to allow fast river flow, or the location of the recipient cell is calculated based on the amount of head in the donor cell, after which in one time step the full amount of water is moved over several cells downstream along the flow path determined by the link map. The number of iterations or the length of the flow path needed for the hydrologic module is calibrated so that the water flow rates match gage data.

Another algorithm checks that water movement stops when the water heads in two adjacent cells equilibrate. We examine the flow between two adjacent cells as flow in an open channel and use the "slope-area method" (Boyer 1964), which is a kinematic-wave approximation of St. Venant's momentum equation. The flux (measured in cubic meters per day) in this case is de- scribed by the empirical Manning's equation for overland flow. The equation is further modified to ensure that there is no flux after the two cells equilibrate, and the flux rate is then accelerated using the multicell dispersion algorithm discussed by Voinov et al. (1998). While the first algorithm works well for the piedmont area with significant elevation gradients, the second is more appropriate for the coastal plain region where there are significant areas of low relief and tidal forces that permit counterflows.

For the saturated water, a modified Darcy equation was employed. For each cell, the flux was determined as a function of saturated conductivity and water head difference between the current cell and the mean head of the cell and its eight neighbors. We assume one vertically homogenous aquifer interacts with the surface water.

\section{Economic land-use conversion (ELUC) model}

Spatially explicit data on property sales and many of the economic and ecological characteristics of areas in spatial proximity to these sales were available for the seven counties encompassing the Patuxent watershed. This allowed land-use change to be empirically modeled in a spatially disaggregated way. The model estimates probabilities of land conversion from forest or agriculture to different densities of residential use within each spatial cell in the seven-county area of the Patuxent basin (Bockstael et al. 1995, Bockstael 1996, Bockstael and Bell 1998, Geoghegan et al. 1997).

The model consists of two stages. The first stage estimates the value of land parcels in different uses. The assessed value of any structures was subtracted from data on the selling price to get the residual value of the land in residential use. This land value was used as the dependent variable, and spatial variation in land prices were explained by an extensive array of features of the location, including distance to employment centers, access to public infrastructure (roads, recreational facilities, shopping centers, sewer, and water services), and proximity to desirable (e.g., waterfront) and undesirable (e.g., waste dump) land uses. Also included were some less obvious explanatory variables that describe the nature of the land uses surrounding a parcel. The estimation techniques used were maximum likelihood and generalized method of moments, the latter being an approach that allows for treatment of the obvious spatial autocorrelation in the model.

The second stage involved estimating "qualitativedependent variable" models (i.e., discrete choice models) of historical land-use conversion decisions. In this stage, historical decisions as to whether or not to convert a parcel in an agricultural or forest use to residential use are modeled as functions of their value in original use, predicted value in residential use (derived from the first-stage model), and proxies for the relative costs of conversion. The purpose of this stage was to 
TABLE 1. Ten-year averages for three forest model variables compared to literature values.

\begin{tabular}{|c|c|c|c|c|c|c|}
\hline \multirow[b]{2}{*}{ Age } & \multicolumn{2}{|c|}{$\mathrm{NPP}\left(\mathrm{kg} \cdot \mathrm{m}^{-2} \cdot \mathrm{yr}^{-1}\right)$} & \multicolumn{2}{|c|}{$\mathrm{PO}_{4}{ }^{3-}(\mu \mathrm{g} / \mathrm{L})$} & \multicolumn{2}{|c|}{ DIN $(\mu \mathrm{g} / \mathrm{L})$} \\
\hline & Mean & $1 \mathrm{SD}$ & Mean & $1 \mathrm{SD}$ & Mean & $1 \mathrm{SD}$ \\
\hline \multicolumn{7}{|l|}{ Model output } \\
\hline Young & 0.039 & 0.006 & 0.017 & 0.004 & 4.1 & 5.5 \\
\hline Intermediate & 0.29 & 0.014 & 0.025 & 0.019 & 2.7 & 2.6 \\
\hline Old & 0.497 & 0.014 & 0.031 & 0.027 & 4.2 & 3.5 \\
\hline All forest ages & 0.27 & 0.190 & 0.024 & 0.02 & 3.7 & 4.1 \\
\hline \multicolumn{7}{|l|}{ Reference data } \\
\hline All forest ages & $0.14 \dagger$ & 0.67 & $0.185 \S$ & 0.165 & $5 \mathbb{I}$ & 5 \\
\hline
\end{tabular}

determine what factors affect land-use conversion and to estimate parameters of those conversion functions.

Once the parameters of the two stages of the model were estimated, it was used to generate the relative likelihoods of conversion of different parcels in the landscape. A spatial pattern of relative development pressure was obtained as a function of the characteristics of the parcels and their locations. Since the explanatory variables used to predict the values in residential and alternative uses and the costs of conversion are all functions of ecological features, human infrastructure, and government policies, the effects of changes in any of these variables can be simulated. Total growth pressure in the region was then used to estimate the spatial patterns of new residential development into the future. For example, to generate the scenarios used in this paper, we used a projection of 28000 new dwelling units in the five years 1997-2003 in the seven counties that include the Patuxent watershed. Other alternatives for growth pressure could also be analyzed, but this seemed to be the consensus opinion on growth pressure in the near term. The new dwelling units were then distributed in the watershed in the "most likely" locations based on the results of the stage 1 and 2 modeling exercises that we have described.

\section{RESULTS}

Much of the time involved in developing spatial process-based models is devoted to calibration and testing of the model behavior against known historical or other data (Costanza et al. 1990). To adequately test model behavior and to reduce computational time, we performed the calibration and testing at several time and space scales, and for the unit model independently of the full spatial model. These tests and their results are briefly described here, followed by results of various scenarios using the calibrated model. These scenarios address both the underlying behavior of the landscape and the implications of various proposed management options.

\section{Unit model calibration}

The general ecosystem model (GEM) has been previously calibrated for the Everglades National Park and Water Conservation Areas (Fitz et al. 1995), which hosts a plant community dominated by perennial herbaceous species (e.g., sawgrass). In contrast, the dominant Patuxent plant community is forest. We have carried out a systematic investigation of the behavior of the GEM across its parameter space. The calibration presented here simulates a 10 -year period using a constant weather regime for each year, beginning in 1986. Field monitoring at 12 forested sites located within the eastern United States (Johnson and Lindberg 1992) provided mean flux rates and organic matter nutrient contents for input and calibration. Parameters in the unit model are for an average unit area $\left(1 \mathrm{~m}^{2}\right)$. They are multiplied by the area of each cell later in the spatial simulation. Input parameters for driving the hydrological functions are mean values from the State Soil Geographic (STATSGO) database for the Patuxent watershed (see the Appendix). Biomass and species composition were derived through the Forest Inventory and Analysis Database (FIA) (see the Appendix). The forest association used to select data was oak-hickory with $0.6 \%$ coniferous trees. External input of nutrients was through precipitation, while dissolved concentrations were allowed to leave the system with the groundwater flow. The consumer sector was made inactive in anticipation of stronger supporting data currently being developed.

The calibration was run for three different stages in forest development. At the first or young stage the forest biomass is set at $10 \%$ of the maximum attainable biomass, which is based on the 75th percentile value for oak-hickory in the FIA. The second stage (intermediate) is set at $50 \%$ of the maximum biomass, while the third stage (old) is set at $90 \%$ of the maximum biomass. Ten-year averages of inorganic phosphate concentrations $\left(\mathrm{PO}_{4}{ }^{3-}\right)$, dissolved inorganic nitrate concentrations (DIN), net primary production (NPP) (Ta- 

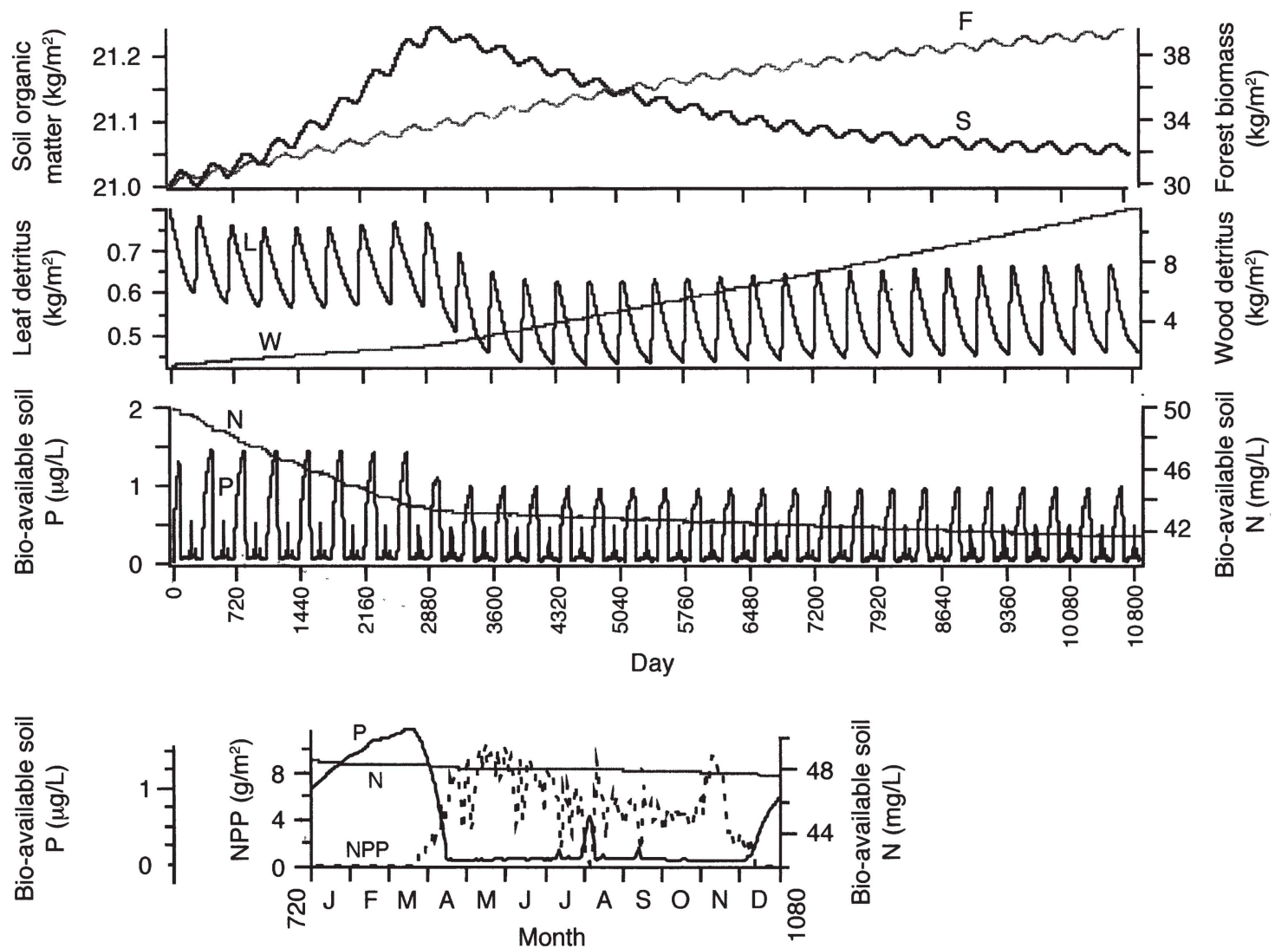

FIG. 6. Daily output for the soil organic matter, forest biomass, leaf detritus, wood detritus, bio-available soil phosphorous, and bio-available soil nitrogen stocks from calibration runs simulating 10 years of forest growth. Also shown is one year of phosphorous, nitrogen, and net primary production (NPP) on an expanded time scale. Curves, top to bottom, are as follows: F, forest; S, soil; L, leaf detritus; W, wood detritus; N, nitrogen; P, phosphorus; and NNP, net primary productivity.

ble 1), detrital matter, and nonliving soil organic matter (NLOM) are compared to similar values available through the FIA database for the Patuxent watershed or literature on temperate forests.

As expected, the older forest showed the largest amounts of detrital and soil organic matter. The soil organic matter values in the old and intermediate forest exceed the mean +1 SD (Fig. 6) because of the lack of consumer appropriation of plant biomass, which is instead routed to the organic matter pool through the detrital pathway. In contrast to the intermediate or young forests, old forest was able to sustain high net primary production that caused a steady increase in the soil organic matter. After seven years of simulation the old forest detrital matter production decreased due to growth-limiting factors and nutrient limitations. The young forest became increasingly phosphate limited, which resulted in a 10-year decrease in NPP and NLOM. This is consistent with the notion that deciduous forests use more nutrients and are leakier during early stages in forest growth when compared to pines, which are more conservative in their use of nutrients and thus have a early competitive advantage (Reich et al. 1992, Gholz et al. 1994).
Nutrient concentrations during the 10-year simulation runs tend to stay within the limits reported in the literature (Table 1). The standard deviations in the single-age runs were lower than would be expected from a spatial run showing mixed ages in the landscape. The literature values represent means of the more variable mixed ages. The forests in all age stages had transitional loads of DIN and low values of inorganic phosphate. Net primary production through the simulation was approximately twice the NPP derived from the FIA database, but well within the range of one standard deviation (Table 1). This makes sense, since the FIA data is focused on timber (aboveground, woody) production and does not account for belowground and herbaceous production. Only one-third of the variation in $\mathrm{NPP}$, and $1 / 10$ in $\mathrm{PO}_{4}{ }^{3-}$ was captured during the unit model calibration runs. Larger ranges in variation for these two variables are expected when calibrating the spatial model on a larger variety of soil conditions. In contrast, the unit model calibration did account for most of the variation in DIN, as variation in the nitrogen cycle is less soil specific and more controlled by atmospheric concentrations of gaseous nitrogen species (Gardner et al. 1996). 
TABLE 2. Patuxent landscape model (PLM) testing and comparison to the Hydrologic Simulation Program-Fortran (HSPF) model statistics for the Cattail Creek and Unity subwatersheds, as well as the half subwatershed draining at Bowie.

\begin{tabular}{|c|c|c|c|c|c|c|c|c|c|}
\hline \multirow{3}{*}{$\begin{array}{l}\text { Summary } \\
\text { statistic }\end{array}$} & \multicolumn{5}{|c|}{ Cattail } & \multicolumn{4}{|c|}{ Unity } \\
\hline & \multirow[b]{2}{*}{ Data } & \multirow[b]{2}{*}{ Model } & \multicolumn{2}{|c|}{ Percent error } & \multirow[b]{2}{*}{ Data } & \multirow[b]{2}{*}{ Model } & \multicolumn{2}{|c|}{ Percent error } & \multirow[b]{2}{*}{ Data } \\
\hline & & & PLM & $\mathrm{HSPF} \dagger$ & & & PLM & HSPF† & \\
\hline Total Flow & 2510.41 & 2527.58 & 0.7 & 8.2 & 3950.54 & 3981.31 & 0.8 & -2.1 & 36617.43 \\
\hline $\operatorname{Max} 10 \%$ & 930.2 & 925.79 & -0.5 & 4.9 & 1410.15 & 2148.13 & 41.5 & 2.3 & 12497.58 \\
\hline Min $50 \%$ & 587.3 & 596.25 & 1.5 & -14.7 & 826.76 & 626.78 & -27.5 & -12.1 & 7917.98 \\
\hline Total 1986 & 326.16 & 282.24 & -15.6 & -0.7 to +18.1 & 484.52 & 446.30 & -8.2 & -11.6 to +8.0 & 4752.94 \\
\hline Total 1987 & 472.83 & 469.25 & -0.8 & -0.7 to +18.1 & 816.48 & 942.00 & 14.3 & -11.6 to +8.0 & 6446.08 \\
\hline Total 1988 & 482.01 & 414.22 & -16.4 & -0.7 to +18.1 & 819.30 & 792.10 & -3.4 & -11.6 to +8.0 & 6751.99 \\
\hline Total 1989 & 660.62 & 748.29 & 11.7 & -0.7 to +18.1 & 960.30 & 949.45 & -1.1 & -11.6 to +8.0 & 10507.98 \\
\hline Total 1990 & 568.78 & 611.31 & 6.9 & -0.7 to +18.1 & 869.94 & 851.47 & -2.1 & -11.6 to +8.0 & 8158.45 \\
\hline
\end{tabular}

$\dagger$ The ranges of values for the HSPF-model percent error for 1986-1990 represent a composite across the included set of years.

The same contrast between $\mathrm{PO}_{4}{ }^{3-}$ and DIN sources (soil vs. atmospheric) is seen in the seasonal model dynamics (Fig. 6) of the young forest, which show little variation over the year in $\mathrm{PO}_{4}{ }^{3-}$ concentration relative to DIN. The low biomass of the young forest forces it to rely on the slow release of $\mathrm{PO}_{4}{ }^{3-}$ from a mineral soil, but DIN remains more readily available through wet deposition. As biomass in the forest increases, nutrient dynamics are more controlled by the mineralization of organic matter and plant uptake rates, which provide a larger pool of available nutrients. This leads to less dramatic changes in nitrogen, but more seasonal variation in phosphate in the older forests.

Agricultural land uses were simulated in GEM for crops typical of the Patuxent watershed. Crops included typical cycles between corn, winter wheat, and soybeans. The Patuxent-general ecosystem model (Pat-
GEM) was expanded to include decisions on planting, harvesting, and fertilization, while switching between crop-specific growth parameters. Crop production estimates were calibrated against the results from the erosion productivity impact calculator (EPIC), which is a widely used and calibrated agricultural model. High correlations were found between output generated with Pat-GEM and EPIC. The $R^{2}$ value ranged $0.87-0.98$, with results for winter wheat showing the lowest correlation coefficients. Intercalibration using EPIC proved to be a useful "second-best" method for calibrating the Pat-GEM model for agricultural land uses. The erosion productivity impact calculator was able to provide $\sim 30 \%$ of the input data required for running the PLM model, and it also provided time series output data (on a daily step) to compare with the GEM output variable. Since EPIC has been widely tested, we feel

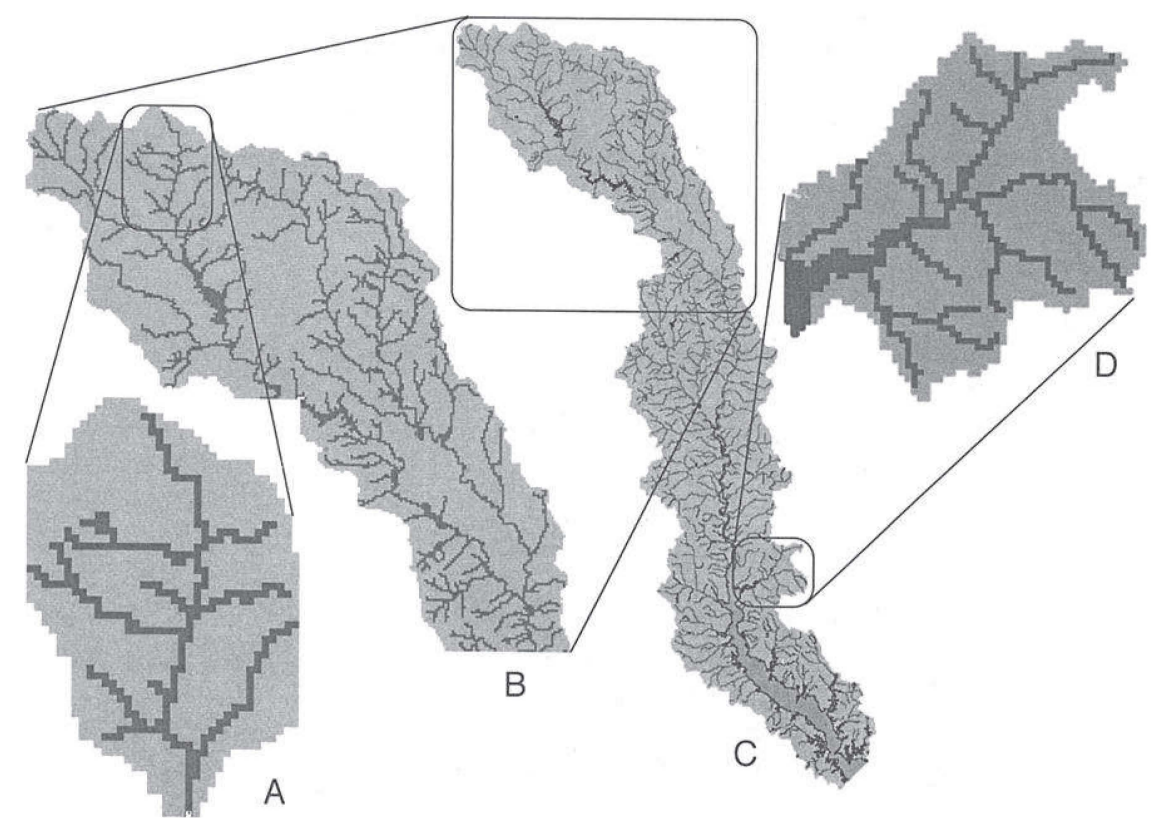

Fig. 7. Hierarchy of subwatersheds in the Patuxent drainage basin used to calibrate and analyze the model: (A) $23-\mathrm{km}^{2}$

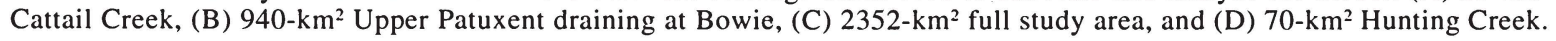


TABLE 2. Extended.

\begin{tabular}{crc}
\hline \hline & \multicolumn{2}{c}{ Bowie } \\
\hline & \multicolumn{2}{c}{ Percent error } \\
\cline { 2 - 3 } Model & PLM & HSPF $\dagger$ \\
\hline 37978.78 & 3.6 & 9.7 \\
16546.70 & 27.9 & 15.1 \\
6582.62 & -18.4 & 9.0 \\
4352.84 & -8.8 & -2.6 to +25.3 \\
7041.22 & 8.8 & -2.6 to +25.3 \\
5841.62 & -14.5 & -2.6 to +25.3 \\
11881.88 & 12.3 & -2.6 to +25.3 \\
8861.23 & 8.3 & -2.6 to +25.3 \\
\hline
\end{tabular}

that replicating its results is a sufficient "second-best" calibration approach in lieu of detailed local time series data.

\section{Spatial hydrology calibration}

Calibrating and running a hydrologic model of this level of complexity and resolution requires a multistage approach (Voinov et al. 1999a). We first identified two spatial scales at which to run the model: a $200-\mathrm{m}$ and $1-\mathrm{km}$ cell resolution. The $200-\mathrm{m}$ resolution was more appropriate to capture some of the ecological processes associated with land-use change, but was too detailed and required too much computer processor time to perform the numerous model runs required for calibration and scenario evaluation for the full watershed. The 1$\mathrm{km}$ resolution reduced the total number of model cells in the watershed from 58905 to 2352 .

Second, we identified a hierarchy of subwatersheds. The Patuxent watershed has been divided into a set of nested subwatersheds to perform analysis at three scales (Fig. 7). The small $\left(23 \mathrm{~km}^{2}\right)$ subwatershed of Cattail Creek in the piedmont northern part of the $\mathrm{Pa}$ tuxent basin was used as a starting point. Another small subwatershed, Hunting Creek, was selected to calibrate the model for the different hydro-ecological conditions of the coastal plain area. The next larger watershed was the upper nontidal half of the Patuxent watershed that drained to the USGS gage at Bowie $\left(940 \mathrm{~km}^{2}\right)$. And finally we examined the whole Patuxent watershed $\left(2352 \mathrm{~km}^{2}\right)$. The number of total model cells grew from 566 cells initially, to 23484 cells for the half watershed, and then to 58905 cells for the entire study area at the 200-m resolution.

In this stage of the calibrations, we ran only the hydrologic component of the model, without links to the plants and nutrients. While transpiration by plants and the influence of nutrients on plant productivity and transpiration are obviously important influences on hydrology, we excluded them at this stage for several reasons: (1) for simplicity; (2) for direct comparison to other hydrologic models; and (3) to test the effects of adding the plant and nutrient dynamics later in the analysis.
We staged a set of experiments with the small Cattail Creek subwatershed to test the sensitivity of the surface water flux. Three crucial parameters controlled surface flow in the model: infiltration rate, horizontal conductivity, and number of iterations per time step of the unit model. River flow peak height was strongly controlled by the infiltration rate. The conductivity determined river levels between storms, and the number of iterations modified the width of the storm peaks.

Surface water flow was calibrated against the 13 USGS gaging stations in the area that have data concurrent with the climatic data series (1990-1996). In this calibration, the model results for the Cattail subwatershed (Fig. 7a) are in fairly good agreement with the data and may be considered as a partial model verification because none of the parameters had been changed after the initial calibration using 1990 data. Some of the flow statistics are presented in Table 2 where we have also included calibration results from the Hydrologic Simulation Program-Fortran (HSPF) (Donigian et al. 1984) that has been previously applied to the Patuxent watershed (AQUA TERRA 1994). We attained a considerably better fit to the data with our model than with HSPF. The Hydrologic Simulation Program-Fortran is a more empirically based model that uses high temporal resolution input data (e.g., hourly rainfall data), but relatively low spatial resolution (e.g., aggregated subwatersheds). Much more of the behavior in HSPF is embedded in the parameters of the model than is the case with the PLM (which uses the pattern of land use to drive much of the behavior). Thus the effects of changes in the spatial pattern of land use (one of our key questions) cannot be adequately addressed using HSPF, since it would require recalibrating the model for the new land-use pattern, and empirical hydrologic data for this new, hypothetical, landuse pattern obviously does not exist.

Next we performed a spatial scaling experiment that involved varying the spatial resolution of the model. In this experiment, we mainly looked at the effects of changing the model resolution, not the data resolution. Using geographic information systems (GIS) operations, we aggregated the model, switching from a 200$\mathrm{m}$ to a $1-\mathrm{km}$ cell resolution. Model runs for the $1-\mathrm{km}$ resolution were remarkably close to the results from the $200-\mathrm{m}$ model. This finding was especially promising for analysis of the other modules of the full ecological economic model. Since most of the horizontal spatial dynamics are governed by the hydrologic fluxes, the coarser $1-\mathrm{km}$ resolution should be sufficient for the spatial analysis of the integrated model of the watershed in this case.

Overall, the model of the half watershed (Fig. 7b) showed less precise model results (Fig. 8) than did the Cattail subwatershed, as predicted from theory (Costanza and Maxwell 1994). The calibration statistics for the half watershed area are summarized in Table 2. In general, the increased spatial extent of the model pre- 


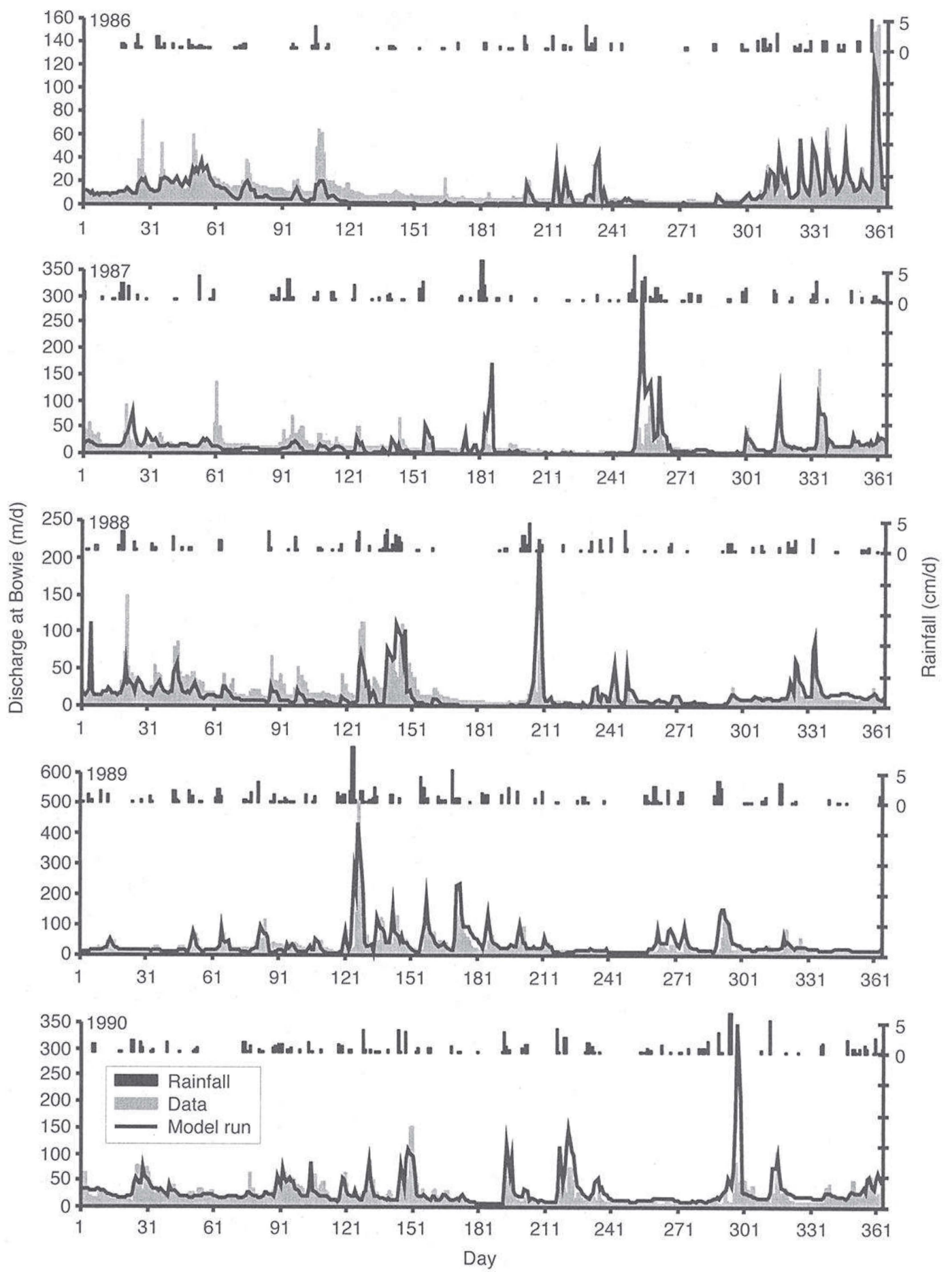

FIG. 8. Hydrologic calibration results for the Upper Patuxent at Bowie for 1986-1990.

sented greater heterogeneity, which was not fully accounted for in the calibration. Specific reasons for this include the following: the spatial resolution of the input climatic data, the greater complexity of groundwater flows at this scale (which are handled in a very simplified way in the model), and the need to recalibrate some of the hydrologic parameters at the larger scale.
One parameter that needed to be adjusted was the number of iterations $N$ in the hydrologic module. At the larger watershed scale, it turned out that a better fit could be obtained if the number of iterations was further increased. Apparently this was because at this larger scale we needed to move water further and faster to better simulate the short-term high peaks that were 
FIG. 9. Calibration results for flow-weighted nitrogen concentrations in the Patuxent River at Bowie for 1990 and 1991.

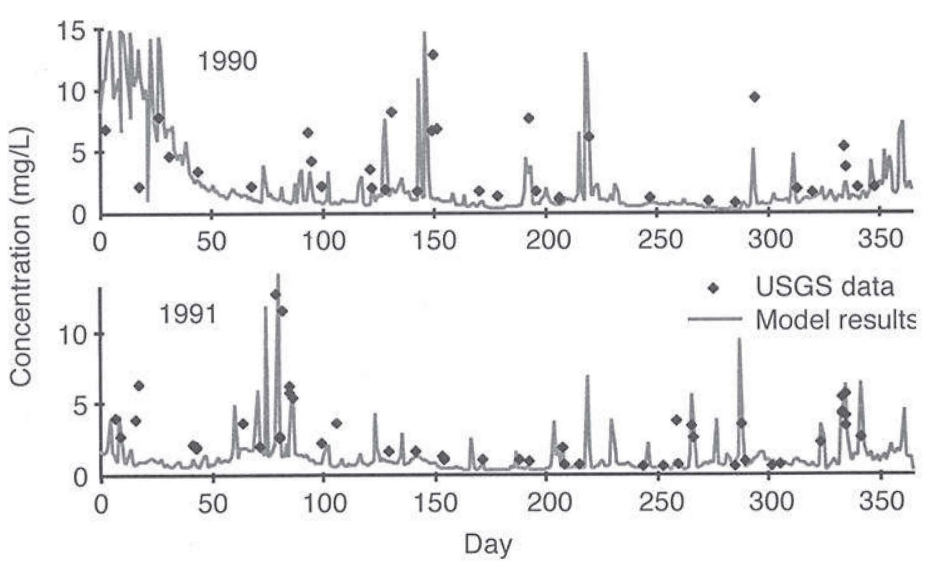

observed in the data. This was a clear illustration of the fact that different scales present new emerging behavior of the system, and that rescaling is an important process that can usually not be done mechanically. The best fit to data was obtained when running the model with the self-adjusting method for $N$ with the maximum number of iterations $m=100$ (Voinov et al. 1999b). Interestingly, the Cattail subwatershed still performed as well as before with this value of $m$. This could be expected since the previous analysis showed no sensitivity of subwatersheds to increases in $N$ beyond 20 $(m=20)$.

Within the subwatershed, we assumed that the groundwater dynamics closely follows the surface water flows and confined the groundwater to the subwatershed area. This is probably not accurate even for Cattail Creek, and at larger scales the groundwater patterns are even more complex.

The spatial rainfall and other data were interpolated from daily records of seven stations distributed over the study area. The Cattail subwatershed hydrology was driven by one climatic station and the half-watershed model incorporated data from three stations. The lack of data on the true variability of the meteorological data in space and time hinders the model's ability to accurately represent short-term or localized responses in river flow. However, the model is able to consider antecedent moisture and runoff-generating areas in a spatially realistic manner based on topography, land use, and soil type, giving the simulation a fairly high degree of precision. The general hydrologic trends seem to be well captured by the model and allow us to expand the study to other modules.

\section{Full ecological model calibration}

The full spatially explicit ecological model was run for several years using historical climate inputs for calibration purposes. In this case, we ran the model at a $1-\mathrm{km}$ spatial resolution. We used two methods to compare the model performance to the available data.

Certain modeled variables, or indices that aggregate model variables, were compared to point time series data such as stream flow, nutrient concentration in the streams, and historical tree ring data for the region (Tables 1 and 2).

The inclusion of plant and nutrient dynamics improved the model's hydrologic performance in comparison to the output already reported. The spatially explicit representation of plant and nutrient dynamics modifies the evapotranspiration and interception fluxes in the model, making the model performance more realistic. It was also essential for scenario runs that take into account land-use and cover changes, in which these changes modify the hydrologic fluxes in the watershed.

A sample of calibration for flow-weighted nitrogen concentrations in the Patuxent River at Bowie is presented in Fig. 9. Data are available to calibrate longer term runs of the model with these data sets. Model output was compared to field data by visually inspecting superimposed graphs and comparing annual mean and total values. For example, the long-term trend of nitrogen dynamics in Hunting Creek (a small subwatershed in the Coastal Plain area) shows good correlation with the annual dynamics calculated from the data.

Comparison of raw spatial data is a much more difficult and less studied procedure. Spatially explicit data is scarce and rarely matches the spatial extent and resolution produced by the model. Some example output for plant primary production from the model is shown in Fig. 10. This shows the typical pattern of seasonal growth in the region, which has a significant impact on hydrology through transpiration. Data derived from advanced, very high resolution radiometer (AVHRR) satellite images, the normalized-difference vegetation index (NDVI) or "greenness" index were used to calibrate the full model's predictions of primary production for intra-annual effects. We created indices from the NDVI data and the model output so that we were comparing the timing and pattern of NDVI change to the timing and pattern of net primary production (NPP) change in the model. A visual comparison shows fairly good agreement between the model output and the data 
currently available. For long-term forest growth calibrations we used the Forest Inventory and Analysis (FIA) data on forest growth (Table 1). The small Cattail Creek subwatershed (which can be run more quickly) was run for 50 years to examine long-term trends. These results compared favorably to the FIA data.

\section{Scenario overview}

The goal of the linked ecological economic model development was to test alternative scenarios of landuse patterns and management. A wide range of future and historical scenarios may be explored using the calibrated model. We have developed scenarios based on the concerns of county, state, and federal government agencies, local stakeholders and researchers. What follows is the set of initial scenarios that have been considered, presented chronologically. The first four listed here constitute a group of historical scenarios based on the USGS reconstruction (Buchanan et al. 1998) of land use in the Patuxent watershed. The next set of four scenarios (5-8) specify a temporal point of reference and emphasis. Scenarios 8-18 all assume the use of best management practices (BMP). Scenarios 9-12 are variations on the economic land-use conversion model (ELUC) of N. Bockstael (Bockstael et al. 1995, Bockstael 1996, Bockstael and Bell 1998) that reflect land use over the five years following 1997 (i.e., through 2003). Scenarios 13-16, on the other hand, study dramatic change in land-use patterns using 1997 land use as the starting point and are designed to show the total contribution of particular land-use types to the current behavior of the system by completely removing them. Finally, scenarios 17 and 18 form a pair of hypothetical scenarios to study the effects of clustering, again using the 1997 land use as the starting point.

1) 1650.-During the predevelopment era, most of the area was forested, with zero emissions.

2) 1850.-During the period of agro-development, almost all of the area was under agricultural use, with traditional fertilizers (e.g., marl, river mud, manure) and low emissions.

3) 1950.-The next historical phase saw a decline of agriculture and the start of reforestation and fast urbanization.

4) 1972.-The final historical period was one of maximal reforestation, intensive agriculture, and high emissions.

5) Baseline scenario.-The year 1990 was chosen as a baseline to compare the modeling results. The 1990-1991 climatic patterns and nutrient loadings were used.

6) 1997 land-use pattern.-This data set has just recently been released, and we used it with the 19901991 forcings to estimate the effect of land-use change alone.

7) Buildout scenario.-With the existing zoning regulations, we assumed that all the possible development in the area occurred. This may be considered as the worst-case scenario in terms of urbanization and its associated loadings.

8) Best management practices (BMP).-1997 land use with lowered fertilizer application and crop rotation. These management practices were also assumed in the remaining scenarios (9-18).

9) Basic economic land-use conversion (ELUC) model.-Development as usual.

10) ELUC with sewers.-Development with all projected sewer systems in place.

11) ELUC with protected forest.-Development with no new sewers, but with contiguous patches of forest protected (areas $\geq 200 \mathrm{ha}$ ).

12) ELUC with sewers and forest.-Development with all sewers in place and contiguous forest protected.

13) Dramatic change, farms to homes.-Conversion of all currently agricultural land into residential.

14) Dramatic change, farms to forest.-Conversion of all currently agricultural land into forested.

15) Dramatic change, homes to forest.-Conversion of all currently residential land into forested.

16) Dramatic change, forest to homes.-Conversion of all currently forested land into residential.

17) Residential clustering.-Conversion of all current low-density residential land use into urban, around three major centers.

18) Residential sprawl.-Conversion of all current high-density urban into residential, randomly spread across the watershed.

The scenarios were driven by changes in the landuse map, the sewers map, patterns of fertilizer application, amounts of atmospheric deposition, and location and number of dwelling units. Since the model is spatially explicit and dynamic, it generates a huge amount of output for each scenario run. We can only present a brief summary here in the form of spatially and temporally averaged values for a few key indicators. Table 3 is a summary of some of the model output from the different scenarios, looking at nitrogen concentration in the Patuxent River as an indicator of water quality, changes in the hydrologic flow, and changes in the net primary productivity of the landscape. Some selected additional results of the scenario runs are now briefly described.

\section{Historical scenarios}

In this group of scenarios (1-4), we attempted to reconstruct the historical development of the Patuxent watershed, starting from the pre-European settlement conditions in 1650 . The 1850,1950 , and 1972 maps (Fig. 11) were produced based on data from Buchanan et al. (1998). In 1650, the watershed was almost entirely forested, with very low atmospheric deposition of nitrogen, no fertilizers, and no septic tank discharges. The rivers had very low nutrient concentrations. By 1850 , the landscape had been dramatically modified by European settlers. Almost all the forests were cleared 


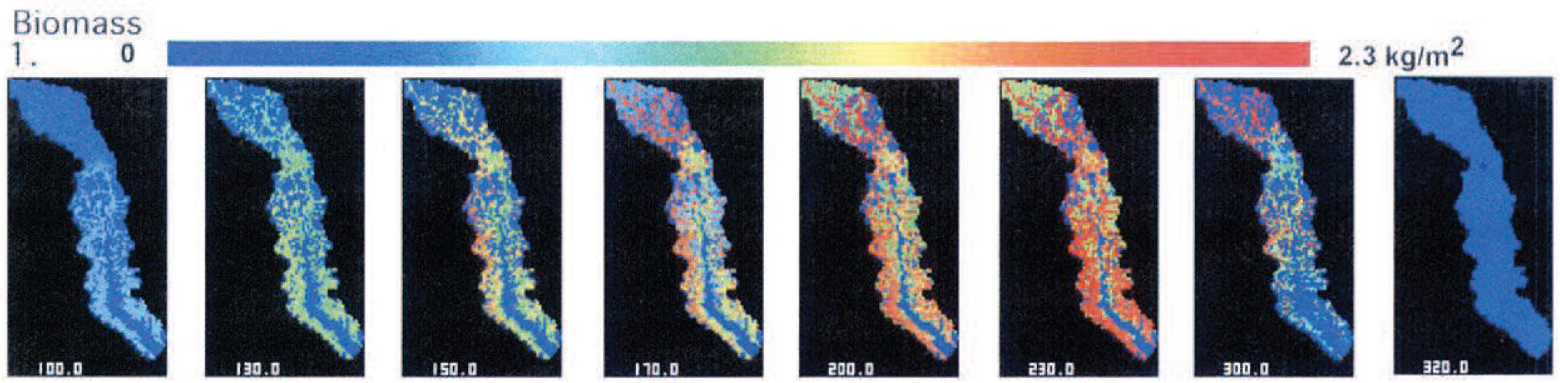

Net Primary Production
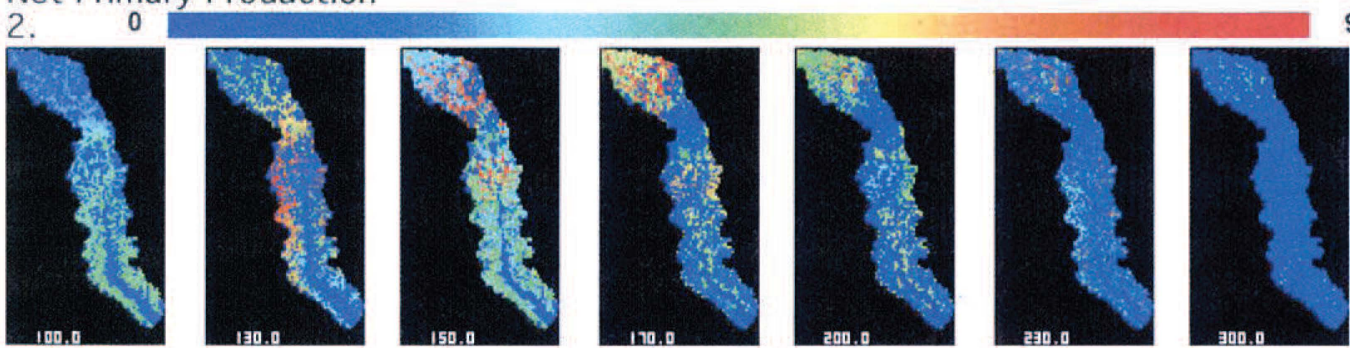

$90 \mathrm{~g} / \mathrm{m}^{2} /$ day

Precipitation
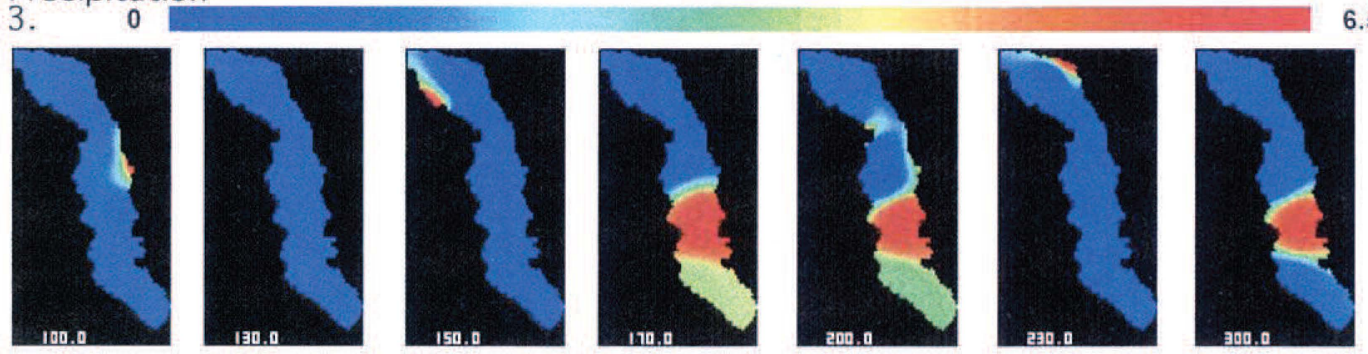

$6.5 \mathrm{~cm} /$ day

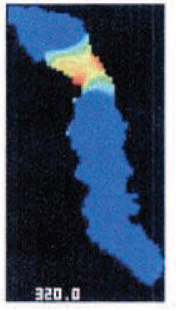

FIG. 10. Sample spatial output of the full model for selected days in an annual simulation: (1) photosynthetic biomass,

(2) net primary production, and (3) rainfall.

and replaced with agriculture (Table 3). However, fertilizers used at the time were mostly organic (manure, river mud, green manure, vegetable matter, ashes), the atmospheric deposition of nutrients was still negligible, and the population was low, producing little septic tank load.

After 1850, agricultural land use began shrinking and forests began regrowing. By 1950 the area of forests had almost doubled. At the same time, rapid urbanization began, primarily along the Washington, D.C.Baltimore corridor. This affected the Patuxent watershed both directly (through changes in land use from agriculture and forests to residential and commercial uses) and indirectly (through increased automobile use in the larger region and increased atmospheric inputs of nutrients). This process continued until the 1970s, when reforestation hit its maximum. Since then, continued urbanization of the area has been affecting both agricultural and forested areas at approximately the same rate. The atmospheric emissions and fertilizer applications were assumed to grow steadily from the low preindustrial levels to modern load levels. The growing population in the residential sectors contributed to increasing discharges from septic tanks.
1990 vs. 1997 vs. "buildout"

Comparison between the 1990 and 1997 model output (scenarios 5 and 6 , respectively) shows that there was a considerable decline in the number of forested and agricultural cells, which was due to the increase in residential and urban areas. Accordingly, fertilizers contributed less to the total nitrogen load for the watershed, whereas the amount of nitrogen from septic tanks increased (Table 3 ). These load totals also demonstrate the relative importance of different sources of nitrogen on the watershed. Under existing agricultural practices the role of fertilizers remains fairly high. Atmospheric deposition contributes unexpectedly high proportions of the nitrogen load. The role of septic tanks may seem minor; however, it should be remenbered that the fate of septic nitrogen is quite different from the pathways of fertilizer and atmospheric nitrogen. Under existing designs of septic drainage fields, the septic discharge is channeled directly to groundwater storage and almost entirely avoids the root zone and nutrient uptake by terrestrial plants.

During 1990-1997 most of the land-use change in the model occurred by replacing forested with resi- 
TABLE 3. Some results of scenario runs for the Patuxent landscape model.

\begin{tabular}{|c|c|c|c|c|c|c|c|c|c|c|c|c|c|}
\hline \multicolumn{2}{|c|}{ Scenario } & \multicolumn{4}{|c|}{ No. cells } & \multicolumn{4}{|c|}{ Concentration $\left(\mathrm{kg} \cdot \mathrm{ha}^{-1} \cdot \mathrm{yr}^{-1}\right)$} & \multicolumn{4}{|c|}{ Concentration $(\mathrm{mg} / \mathrm{L})$} \\
\hline No. & Type & Forest & Resid & Urban & Agro & Atmos & Fertil & Decomp & Septic & $\mathrm{N}_{\text {mean }}$ & $\mathrm{N}_{\max }$ & $\mathrm{N}_{\text {min }}$ & $\mathrm{N}_{\mathrm{gwc}}$ \\
\hline 1 & 1650 & 2386 & 0 & 0 & 56 & 3.00 & 0.00 & 162.00 & 0.00 & 3.14 & 11.97 & 0.05 & 0.023 \\
\hline 2 & 1850 & 348 & 7 & 0 & 2087 & 5.00 & 106.00 & 63.00 & 0.00 & 7.17 & 46.61 & 0.22 & 0.25 \\
\hline 3 & 1950 & 911 & 111 & 28 & 1391 & 96.00 & 110.00 & 99.00 & 7.00 & 11.79 & 42.34 & 0.70 & 0.284 \\
\hline 4 & 1972 & 1252 & 223 & 83 & 884 & 86.00 & 145.00 & 119.00 & 7.00 & 13.68 & 60.63 & 0.76 & 0.281 \\
\hline 5 & 1990 & 1315 & 311 & 92 & 724 & 86.00 & 101.00 & 113.00 & 13.00 & 10.18 & 40.42 & 1.09 & 0.265 \\
\hline 6 & 1997 & 1195 & 460 & 115 & 672 & 91.00 & 94.00 & 105.00 & 18.00 & 11.09 & 55.73 & 0.34 & 0.289 \\
\hline 7 & Buildout & 312 & 729 & 216 & 1185 & 96.00 & 155.00 & 61.00 & 21.00 & 12.89 & 83.03 & 2.42 & 0.447 \\
\hline 8 & BMP & 1195 & 460 & 115 & 672 & 80.00 & 41.00 & 103.00 & 18.00 & 5.68 & 16.41 & 0.06 & 0.23 \\
\hline 9 & LUB 1 & 1129 & 575 & 134 & 604 & 86.00 & 73.00 & 98.00 & 8.00 & 8.05 & 39.71 & 0.11 & 0.266 \\
\hline 10 & LUB2 & 1147 & 538 & 134 & 623 & 86.00 & 76.00 & 100.00 & 11.00 & 7.89 & 29.95 & 0.07 & 0.269 \\
\hline 11 & LUB3 & 1129 & 577 & 134 & 602 & 86.00 & 73.00 & 99.00 & 24.00 & 7.89 & 29.73 & 0.10 & 0.289 \\
\hline 12 & LUB4 & 1133 & 564 & 135 & 610 & 86.00 & 74.00 & 100.00 & 12.00 & 8.05 & 29.83 & 0.07 & 0.271 \\
\hline 13 & agro2res & 1195 & 1132 & 115 & 0 & 86.00 & 0.00 & 96.00 & 39.00 & 5.62 & 15.13 & 0.11 & 0.292 \\
\hline 14 & agro2frst & 1867 & 460 & 115 & 0 & 86.00 & 0.00 & 134.00 & 18.00 & 4.89 & 12.32 & 0.06 & 0.142 \\
\hline 15 & res 2 frst & 1655 & 0 & 115 & 672 & 86.00 & 82.00 & 130.00 & 7.00 & 7.58 & 23.50 & 0.10 & 0.18 \\
\hline 16 & frst 2 res & 0 & 1655 & 115 & 672 & 86.00 & 82.00 & 36.00 & 54.00 & 9.27 & 39.40 & 1.89 & 0.497 \\
\hline 17. & cluster & 1528 & 0 & 276 & 638 & 86.00 & 78.00 & 121.00 & 17.00 & 7.64 & 25.32 & 0.09 & 0.216 \\
\hline 18 & sprawl & 1127 & 652 & 0 & 663 & 86.00 & 78.00 & 83.00 & 27.00 & 8.48 & 25.43 & 0.11 & 0.349 \\
\hline
\end{tabular}

Notes: The historical scenarios (1650-1972) are a reconstruction based on estimates done by the U.S. Geological Survey. The "buildout" scenario was estimated based on the existing zoning maps and the mean population densities for particular land-use types. The buildout conditions represent the "worst-case" scenario. The economic land-use conversion (ELUC) scenarios (LUB 1-4) are based on the model by N. Bockstael (Bockstael et al. 1995, Bockstael 1996, Bockstael and Bell 1998). Other scenarios are described in the text. The table lists the land-use distribution for each scenario, followed by the nitrogen inputs from the atmosphere, fertilizers, decomposition, and septic tanks. Next are the mean, maximum (max), and minimum (min) nitrogen in surface waters, and the max and min water levels in streams. $W_{\max }$ is the total of the $10 \%$ of the flow that is maximal over a one-year period. This represents the peak flow. $W_{\min }$ is the total of the $50 \%$ of flow that is minimal over a one-year period. This is an indicator of the base flow. $\mathrm{N}_{\mathrm{gwc}}$ is the mean concentration of $\mathrm{N}$ in the groundwater. Since groundwater is a fairly slow variable in the model and the model had only one year of relaxation time in the experiments performed, this variable probably does not adapt fast enough to track the changes assumed under the different scenarios. Total net primary production (NPP; measured in $\mathrm{kg} \cdot \mathrm{m}^{-2} \cdot \mathrm{yr}^{-1}$ ) presents the mean across the whole watershed of plant productivity. It reflects the approximate proportion of forested and agricultural land-use types, which have a larger NPP than residential land uses. See text for additional details.

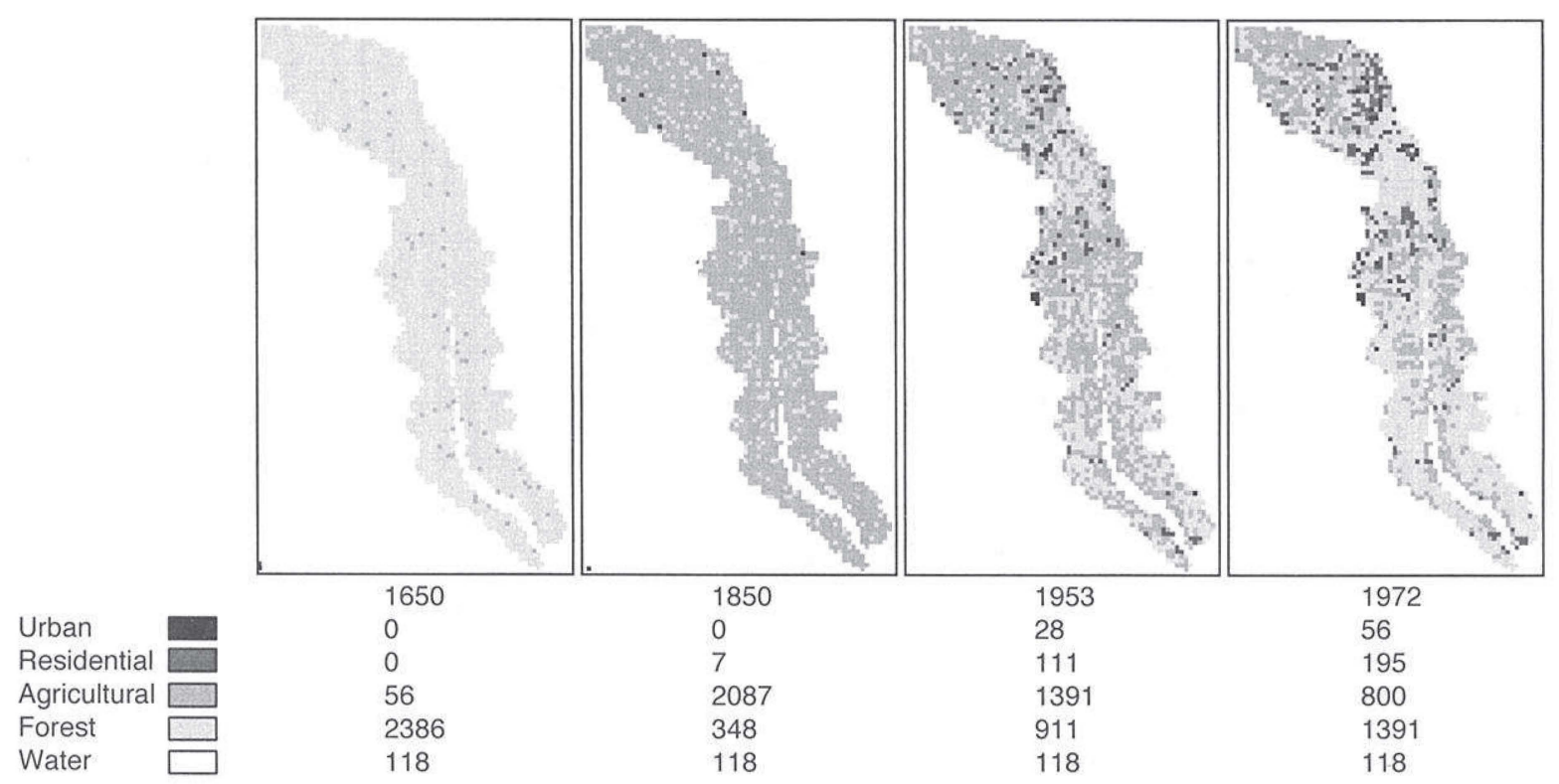

FIG. 11. Approximate reconstruction of Patuxent watershed development for 1650, 1850, 1953, and 1972, based on U.S. Geological Șurvey estimates (Buchanan et al. 1998). 
TABLE 3. Extended.

\begin{tabular}{ccc}
\hline \hline \multicolumn{2}{c}{ Rate $(\mathrm{m} / \mathrm{yr})$} & $\begin{array}{c}\text { Concentration } \\
\left(\mathrm{kg} \cdot \mathrm{m}^{-2} \cdot \mathrm{yr}^{-1}\right) \\
\mathrm{NPP}\end{array}$ \\
\hline$W_{\max }$ & $W_{\min }$ & 2.185 \\
101.059 & 34.557 & 0.333 \\
147.979 & 22.227 & 1.119 \\
128.076 & 18.976 & 1.72 \\
126.974 & 19.947 & 1.654 \\
138.486 & 18.473 & 1.569 \\
147.909 & 18.312 & 0.558 \\
174.890 & 11.066 & 1.523 \\
148.154 & 16.736 & 1.494 \\
150.524 & 17.623 & 1.512 \\
148.353 & 16.575 & 1.5 \\
148.479 & 16.750 & 1.501 \\
148.444 & 16.633 & 1.702 \\
169.960 & 17.586 & 2.258 \\
138.622 & 21.590 & 1.95 \\
120.771 & 20.276 & 0.437 \\
183.565 & 9.586 & 1.792 \\
166.724 & 17.484 & 1.222 \\
140.467 & 17.506 &
\end{tabular}

dential land-use types. As a result, we do not observe any substantial decrease in water quality in the Patuxent River (Table 3). The changes in hydrologic parameters that are associated with the substitution of residential areas for forested and agricultural ones result in somewhat more variability in the flow pattern; however, this difference is not very large. Apparently, during this time period, the residential land use is still less damaging than agricultural use, and the loss in environmental quality that is associated with a transfer from forested to residential conditions is compensated by a net gain in a similar transfer from agricultural to residential use.

These trends are reversed when we move on to the "buildout" (BO; scenario 7) conditions in the model. At some point, a threshold is passed after which most of the development occurs due to deforestation and the effect of residential and urban use becomes quite detrimental to the water quality and quantity in the watershed. The base flow (represented by the $50 \%$ minimal flow values) decreases to almost half of the predevelopment 1700 conditions, and the peak flows become very high because of the overall increase of impervious surfaces. Accordingly, the nitrogen content in the river water grows quite considerably.

\section{Best-management practices (BMP)}

The next scenario (scenario 8) attempts to mimic the possible effects of BMPs. Government concerns are primarily aimed at nutrient reduction through nonpoint source control and growth management (Maryland Office of Planning 1993) and have the broader goal of improving the groundwater, river, and estuarine water quality for drinking water and habitat uses. Nonpoint source control methods under study include stream buffers, adoption of agricultural and urban BMPs, and forest and wetland conservation. Urban BMPs, or storm water management, involve both new development and the retrofitting of older developments. Growth management includes programs to cluster development, protect sensitive areas, and carefully plan sewer extensions. Clustered development has been proposed and promoted in Maryland as a method to reduce nonpoint sources and preserve undeveloped land.

At this time, we have limited our consideration of BMPs to reduction of fertilizer application. Crop rotation has been assumed previously as a standard farming practice in the area. In addition to that, we assessed the potential for nutrient reduction in the Patuxent from reductions achieved by farmers in the basin who have adopted farm nutrient management plans. The Maryland nutrient management program (NMP) enlists farmers who are willing to create and implement nutrient management plans that use a variety of techniques to lower application rates including nutrient crediting with and without soil testing, setting realistic yield goals, and manure testing and storage. The biggest gains for farms without animal operations tended to come from adjusting yield goals (P. Steinhilber 1996, Coordinator of the NMP, personal communication). From this information, we created an expected nutrient reduction of $10-15 \%$, which is the typical reduction for farms in the NMP (T. Simpson 1996, Maryland Department of Agriculture [MDA], personal communication). Another major source of fertilizer application reduction is the recognition by farmers of the contribution of atmospheric deposition when they are calculating their nutrient requirements. This has been promoted by some of the recent recommendations issued by MDA. As a result, we get quite a considerable change in fertilizer loading, and reduction of agricultural land use in the watershed becomes no longer beneficial for water quality in the river (Table 3 ).

\section{Economic land-use conversion (ELUC) model scenarios}

This group of scenarios (9-12) distributes 28000 projected new dwelling units (using 1997 conditions as a base) within the area of the seven counties that include the Patuxent watershed, under certain assumptions about the location of sewers and forest preservation strategies. Most of the change occurs in the upper Patuxent portion of the watershed. As seen from Table 3, the resulting changes in land-use distributions were not as dramatic as during the 1990-1997 period. Correspondingly, the changes in water quality in the river were quite subtle. Our indicators show $<1 \%$ change relative to the 1997 conditions. However, it is noteworthy that in these scenarios, contrary to the previous period, most of the land-use change is from agricultural to residential habitats. The reduction of agricultural loadings turns out to be more important than the increase in septic tank discharges. Because of the high primary productivity of agricultural land use relative to residential, we also observe a decline in mean 
NPP. Apparently these changes do not bring us to the threshold conditions after which the residential trends of development become especially damaging to the environmental conditions.

\section{Hypothetical scenarios}

In the next group of scenarios (13-18), we considered some more drastic changes in land-use patterns. None of these are realistic, but they allow one to estimate the relative contributions of major land-use types to the current behavior of the system. They were also essential to evaluate the overall robustness of the model and to estimate the ranges of change that the model could accommodate. For example, by comparing scenarios 14 and 15, one can see that agricultural land uses currently play a larger role in the nutrient load received by the river than residential land uses, even under the BMPs. We get a considerable gain in water quality by transferring all the agricultural land into residential. Contrary to expectations, cluster development (scenario 17) did not turn out to be any better for river water quality than residential sprawl (scenario 18). Because of larger impervious areas associated with urban land use, the peak runoff dramatically increased in this scenario. This in turn increased the amount of nutrients washed off the catchment area. Cluster development would be beneficial only if it were accompanied by effective sewage and storm water management, thus reducing runoff and providing sufficient retention volumes to channel water off the surface and into the groundwater storage. It should be noted, however, that in our definition of these scenarios we have only modified the land-use maps in terms of the limited number of aggregated categories that we are distinguishing. The changes in the infrastructure (e.g., roads, communications, sewers) that should be associated with the cluster vs. sprawl development have not yet been taken into account.

Conversion of all currently forested areas into residential (scenario 16) was almost as bad as the buildout scenario (scenario 7). However, the crop rotation assumed in scenario 16 somewhat decreased the amounts of fertilizers applied and resulted in lower overall nitrogen concentrations. The septic load in this case was so large because the transition to residential land use was assumed to occur without the construction of sewage treatment plants. In the buildout scenario, most of the residential and urban dwellings were created in areas served by existing or projected sewers.

\section{Summary of scenario results}

One major result of the analysis performed thus far is that the model behaves well and produces plausible output under significant variations in forcing functions and land-use patterns. It can therefore be instrumental for analysis and comparisons of very diverse environmental conditions that can be formulated as scenarios of change and further studied and refined as additional data and information are obtained. The real power of the model comes from its ability to link spatial hydrology, nutrients, plant dynamics, and economic behavior via land-use change. The economic submodel incorporates zoning, land-use regulations, and sewer and septic tank distribution to provide an integrated method for examining human response to regulatory change. The projections from the economic model of land-use change based on proposed scenarios shows the probable distribution of new development across the landscape so that the spatial ecological aspects can be evaluated in the ecological model. The model allows fairly site-specific effects to be examined as well as regional impacts, so that both local water quality and Chesapeake Bay inputs can be considered.

The scenario analyses also demonstrated that the $\mathrm{Pa}-$ tuxent watershed system is complex and its behavior is counterintuitive in many cases. For example, in the entirely forested watershed of 1650 the flow was very well buffered and showed moderate peaks and fairly high base flow. The agricultural development that followed in the next century actually decreased both the peak flow and the base flow, contrary to what one would expect, even though the decrease in the base flow was much more significant than the decrease in the peaks. Apparently, evapotranspiration rates for the kinds of crops currently included in the model were high enough to keep the peaks down. Comparing the effects of various land-use change scenarios on the water quality in the river (Fig. 12) similarly shows that the connection between the nutrient loading to the watershed and the nutrient concentration in the river is complex and difficult to anticipate or generalize. This merely confirms the need for a complex, spatially explicit simulation model of the type we have developed here.

Nevertheless, a few general patterns emerge from analysis of the scenario results, including the following:

1) As previously observed (Krysanova et al. 1999), the effects of temporarily distributed loadings are less pronounced than those that are event-based. For example, fertilizer applications that occur once or twice a year increase the average nutrient content, especially the maximum nutrient concentration (quite significantly), whereas the effect of atmospheric deposition is much more obscure. The difference in atmospheric loading between scenarios 1 and 3 is almost two orders of magnitude, yet the nutrient response is only five to six times higher, even though loadings from other sources also increase. Similarly the effect of septic loadings that occur constantly is not so large. The average $\mathrm{N}$ concentration is well correlated $(r=0.87)$ with the total amount of nutrients loaded. The effect of fertilizers is most pronounced among the individual factors $(r=0.82)$, while the effect of other sources is much less (septic, $r=0.02$; decomposition, $r=-0.40$; atmosphere, $r=0.71$ ). The fertilizer application rate determines the maximum nutrient concentrations $(r=$ 


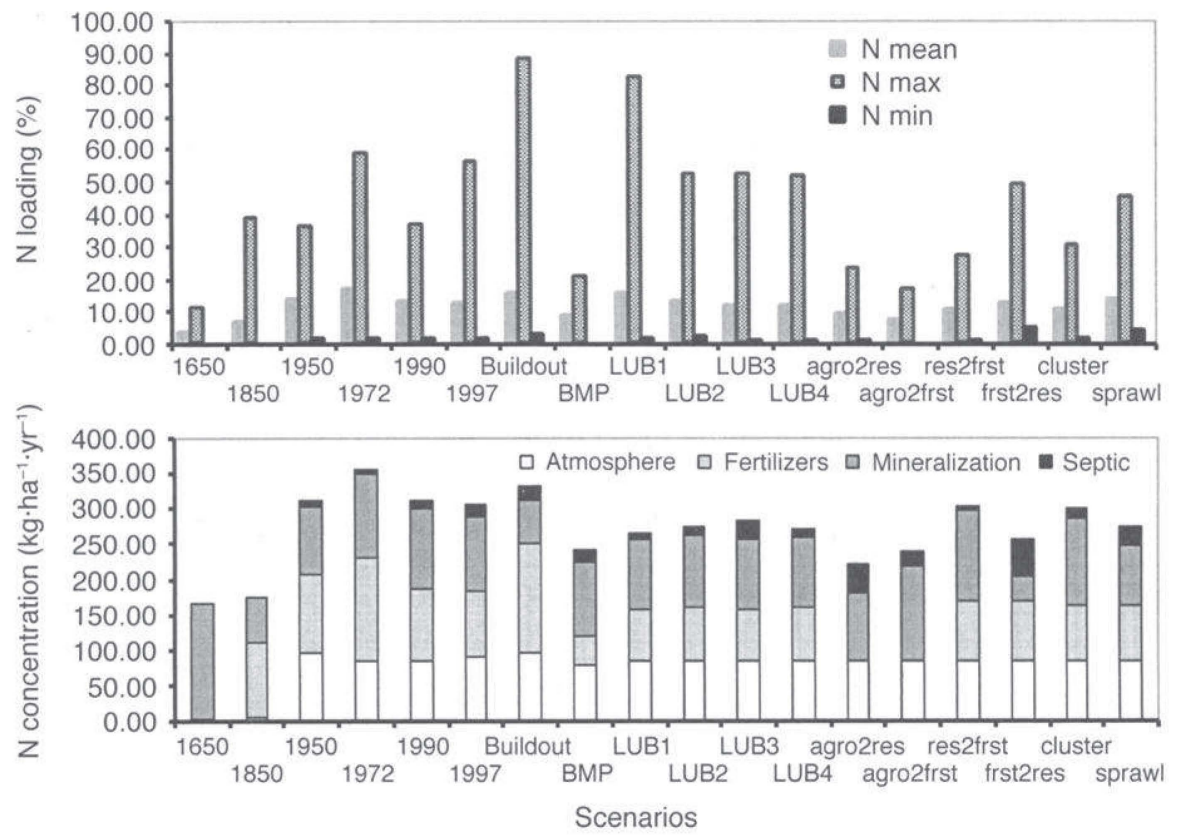

FIG. 12. Nitrogen loading and concentration of nitrogen in the Patuxent River under different scenarios of land use.

0.76), with the total nutrient input also playing an important role ( $r=0.55$ ). Even the groundwater concentration of nutrients is related to fertilizer applications $(r=0.64)$; however, in this case the septic loadings are more important $(r=0.68)$, even more important than the total $\mathrm{N}$ loading $(r=0.52)$.

2) The hydrologic response is quite strongly driven by the land-use patterns. The peak flow (maximum $10 \%$ of flow) is determined by the degree of urbanization ( $r$ $=0.61$ ). The base flow (minimum $50 \%$ of flow) is very much related to the number of forested cells $(r=0.78)$, but in both cases there are obviously other factors involved.

3) We used the net primary productivity (NPP), excluding agriculture and urban areas, as an indicator of ecosystem health and ecosystem services. The NPP is primarily provided by forested areas in the watershed. Different land-use patterns result in quite significant variations in NPP, both in the temporal (Fig. 13) and in the spatial (Fig. 14a, b) domains. The predevelopment 1650 conditions produce the largest NPP; under buildout conditions, NPP is the lowest. Interestingly, as seen from the changes in the spatial distribution of NPP (Fig. 14), there are certain areas that currently produce higher NPP than in 1650. This is because of increased nutrient availability due to atmospheric deposition and fertilizer applications in adjacent agricultural areas.

\section{Discussion}

Linked ecological economic models like the Patuxent landscape model (PLM) are potentially important tools for addressing issues of land use change at the regional watershed scale. The model integrates our current understanding of ecological and economic processes at the site and landscape scales to give estimates of the effects of spatially explicit land-use or land management changes. The model also highlights areas where knowledge is lacking and where further research should be targeted. Specifically, the PLM represents advances in the following areas:

1) The model links topography, hydrology, nutrient dynamics, and vegetation dynamics at a fairly high temporal (single-day) and spatial (200-m) resolution with land-use patterns and the longer term dynamics of land-use change. As far as we know, it is the most advanced model of its type for application at the regional watershed scale.

2) The model allows the explicit assessment of the impacts of the spatial pattern of land use on a large range of ecological indicators, thus providing decision makers and the public with information about the consequences of specific land-use patterns.

3) The model has been extensively calibrated over several time and space scales, which is a difficult and often-ignored operation for models at this scale and complexity. New methods based on multiple-criteria decision models were developed for this purpose.

4) The model operates at several scales simultaneously, including the site (or unit model) scale and the landscape scale, which integrates all the unit models.

5) The model is process-based, with processes changing in dominance over time. This allows better understanding of the underlying phenomena occurring on landscapes and therefore more detailed predictions 


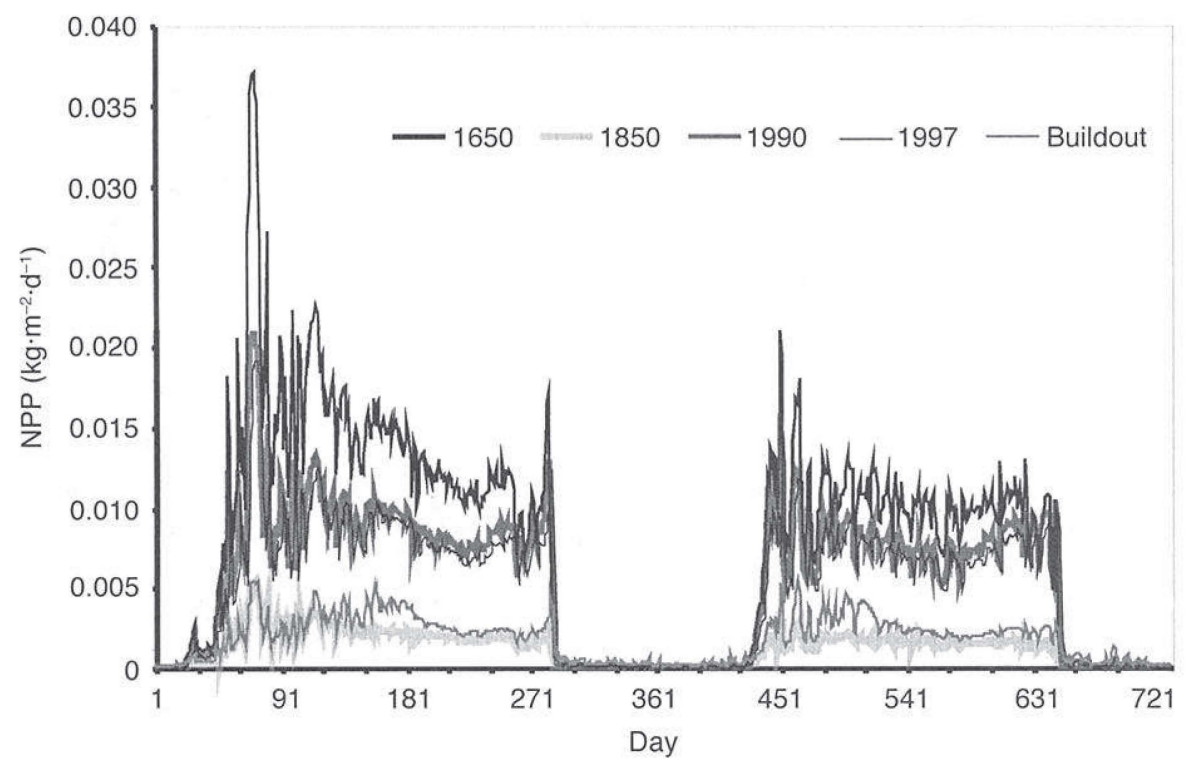

FIG. 13. Variations in dynamics of net primary production (NPP) under various scenarios.

of the possible results of changing land uses and policies.

6) While the model is formulated deterministically, extensive sensitivity analysis allows us to understand its complex dynamics without resorting to multiple stochastic replications. In the full spatial mode, when cells change from one land-use type to another, a bifurcation threshold is simulated, and all the parameters in the cell change to those of the new land-use type.

7) The high data requirements and computational complexities for this type of model mean that development and implementation are relatively slow and expensive. However, for many of the questions being asked this complexity is necessary. We have tried to find a balance between a simple, general model that minimizes complexity and one that provides enough process-oriented, spatially, and temporally explicit information to be useful for management purposes (Costanza and Maxwell 1994).

8) Spatial data is becoming increasingly available for these types of analyses and our modeling framework is able to effectively use this data to model and manage the landscape. One can also use the model to estimate the value of specific data collection investments for a particular model, watershed, and set of goals.

\section{Ecosystem health and services}

One of the primary goals of this type of modeling is the assessment of the impacts of patterns of land use. But impacts on what? Water quality is one obvious endpoint, but it is really a much broader endpointsomething more like the overall quality, "health," or "integrity" of the environment-that is of interest (Costanza et al. 1992, Rapport et al. 1998). The ques- tion then becomes the following: How does one assess the overall quality or "health" of the environment, integrating over a broad range of indicators and stakeholders? One approach to this problem is the notion of "ecosystem services," those functions of ecosystems that support, directly or indirectly, human well-being. This notion resonates with a broad range of stakeholders and also can be used to put ecological and economic services in a common metric for comparison (Costanza et al. 1997). We are actively pursuing linking our work with models with an assessment and valuation of ecosystem health and services, as these may be the most readily understandable and comprehensive measures of performance in regional landscapes.

\section{"Smart growth"}

The PLM model can be used to analyze the impacts of specific development and/or regulatory policies. A couple of our current scenarios deal directly with these issues. For example, the policy sometimes referred to as "smart growth" has achieved some currency and has been advocated by several states, including Wisconsin and Maryland. "Smart" in this context is usually taken to mean "clustered" rather than "sprawled" development of new residential and commercial activities on the landscape. Scenarios 17 (residential clustering) and 18 (residential sprawl) look at the effects of a hypothetical clustering or sprawling of the existing residential land uses. The clustering scenario converts all current low-density residential land uses in the watershed to urban around three major centers, leaving everything else the same as the base case scenario. The sprawl scenario converts all current high-density urban into residential, randomly spread around the watershed. Table 3 shows some of the characteristics and impacts 


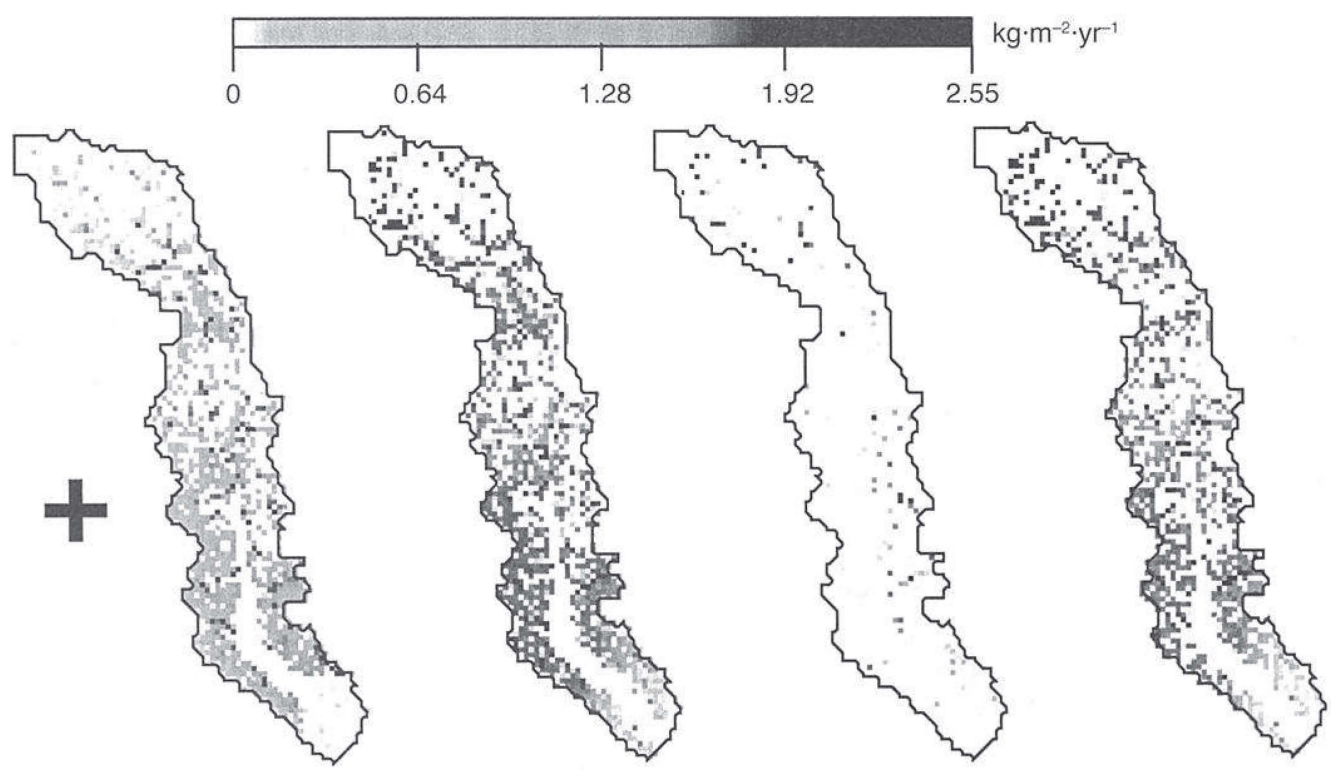

A) $1997-1650$

B) $1997-1850$

C) $1997-1990$

D) 1997-Buildout
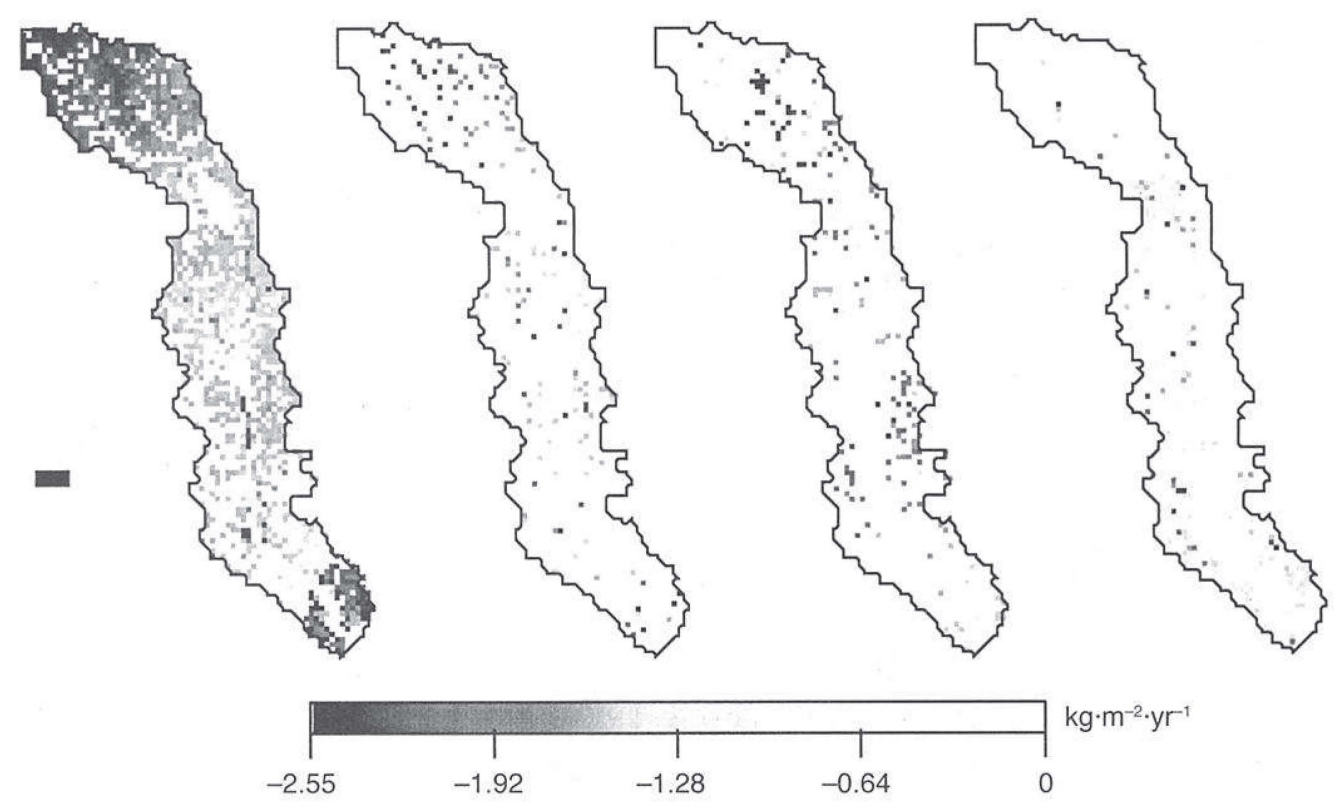

FIG. 14. Spatial distribution of change in net primary production (NPP) for various scenarios compared to the 1997 base case. The upper panel shows those cells for which the base case had larger NPP than the scenario; the lower panel shows those cells for which the base case had smaller NPP than the scenario.

of these scenarios. Compared to the 1997 baseline, the clustered scenario had $276 \mathrm{~km}^{2}$ of urban use compared to $92 \mathrm{~km}^{2}$, and $0 \mathrm{~km}^{2}$ of residential compared to 311 $\mathrm{km}^{2}$, while the sprawled scenario had $652 \mathrm{~km}^{2}$ of residential and $0 \mathrm{~km}^{2}$ of urban. Forest and agricultural areas and nutrient inputs were adjusted accordingly. For example, the clustered scenario had an mean value of $17 \mathrm{~kg} \cdot \mathrm{ha}^{-1} \cdot \mathrm{yr}^{-1}$ of $\mathrm{N}$ input from septic tanks, compared to $18 \mathrm{~kg} \cdot \mathrm{ha}^{-1} \cdot \mathrm{yr}^{-1}$ for the base case and 27 $\mathrm{kg} \cdot \mathrm{ha}^{-1} \cdot \mathrm{yr}^{-1}$ for the sprawled scenario. The sprawled scenario also had mean fertilizer $\mathrm{N}$ input (101 $\mathrm{kg} \cdot \mathrm{ha}^{-1} \cdot \mathrm{yr}^{-1}$ ) larger than either the clustered scenario (89 $\left.\mathrm{kg} \cdot \mathrm{ha}^{-1} \cdot \mathrm{yr}^{-1}\right)$ or the base case scenario (100 $\mathrm{kg} \cdot \mathrm{ha}^{-1} \cdot \mathrm{yr}^{-1}$ ), due to additional inputs from more lawns. The clustered scenario is better in terms of $\mathrm{N}$ in streams, with lower values of the mean $(10.5 \mathrm{mg} / \mathrm{L})$ and maximum $(30.06 \mathrm{mg} / \mathrm{L}) \mathrm{N}$ concentrations than the base case (12.37 and $56.00 \mathrm{mg} / \mathrm{L}$, respectively) and approximately the same value for $\mathrm{N}_{\min }$ (1.33 vs. 1.37 $\mathrm{mg} / \mathrm{L})$. The sprawled scenario is much worse with 13.5 , 
45.14 , and $3.55 \mathrm{mg} / \mathrm{L}$, respectively. The clustered scenario is a bit ambiguous in terms of hydrology compared to the base case, with higher maximum and minimum water levels in streams ( $W_{\max }$ and $W_{\min }$; see Table 3 ). This is due to the increased storm water runoff from urban areas vs. dispersed residential. This effect could be ameliorated with adequate urban storm water management, which was not assumed to be present in the current scenario run. The sprawled scenario had a lower $W_{\max }$ and approximately the same $W_{\min }$ compared to the base case, due to the replacement of agricultural land with low-density urban use. Groundwater $\mathrm{N}$ was lower in the clustered and higher in the sprawled scenarios than in the base case. Finally, NPP was significantly higher in the clustered scenario $\left(1.868 \mathrm{~kg} \cdot \mathrm{ha}^{-1} \cdot \mathrm{yr}^{-1}\right)$ than the base case $\left(1.627 \mathrm{~kg} \cdot \mathrm{ha}^{-1} \cdot \mathrm{yr}^{-1}\right)$ and lower in the sprawled scenario $\left(1.271 \mathrm{~kg} \cdot \mathrm{ha}^{-1} \cdot \mathrm{yr}^{-1}\right)$. Higher NPP correlates with a higher production of ecosystem services and a higher quality of life.

\section{Modeling and decision making}

Humans interact with the model in two distinct, but complementary ways. First, stakeholders were involved in developing the model and can use the model to address policy and management issues. In this mode, human decision making is outside the model, but interacts with the model iteratively. The model is affected by decisions stakeholders make via changes the modelers make in response to the stakeholders' input and new scenarios that are run in response to their requests.

In the second mode, human decision making is internalized in the model. Only a few models have attempted to fully integrate ecological systems dynamics and endogenous human decision making (cf. Carpenter et al. 1999), and none of these have been spatially explicit. In this mode, one tries to model the human agent's responses to the changing conditions in each cell, and the changes in built, human, and social capital. So far in the PLM, modeling of human decision making has been limited to the economic land-use conversion model. We are currently adding local socioeconomic dynamics to the unit model to further internalize human decision making.

These two modes are complementary because observing how people make decisions interacting with the version of the model that does not include human decision making can help us understand and calibrate the version of the model that does include human decision making internally.

We have been quite successful so far in using the model in mode one at several scales. Most land-use policy decisions in Maryland are made at the county level, and we have been interacting with several counties (in particular Calvert County) using the model to address land-use policy. decisions. For example, we performed a detailed case study of the Hunting Creek subwatershed for the Calvert County Planning Commission to address questions of land-use impacts on stream water quality. ${ }^{12}$ As stated at the outset, the Environmental Protection Agency (EPA) and other environmental management agencies at the federal level are getting much more involved in watershed and landscape level analysis and policy making. For these agencies, it is not so much the specific results for the $\mathrm{Pa}$ tuxent watershed that are of most interest, but the general technique and the general results that may be applicable to all watersheds. The landscape modeling techniques we have developed are certainly applicable to any watershed, and many of the scenarios reported in this paper are relevant to some of the general policy questions that the EPA and other environmental management agencies are addressing. These include the impacts of buildout (scenario 7), agricultural best management practices (scenario 8), the overall impacts of agriculture (scenario 14) and residential development (scenario 15), and the effects of sprawl and clustering (scenarios 17 and 18). Models like the PLM are essential tools to improve our ability to make informed regulatory policy decisions at the watershed and landscape scales.

\section{Future work}

Future work will consider a range of additional scenarios including climate change scenarios (changing storm frequency and intensity and $\mathrm{CO}_{2}$ enrichment effects on plants) and additional development patterns that reflect specific smart-growth initiatives. The model will also be used in "design mode." A series of stakeholder workshops are planned with the goal of achieving broader consensus on the preferred environmental and economic endpoints for the system. The model can be used to both inform this discussion and to determine the best way to achieve the desired endpoints.

We will also develop methods to use spatial landscape indices (Turner 1989, O'Neill et al. 1992) to link simulation model output to ecosystem processes that are not modeled spatially in the ecological model. Landscape-level analysis of land-use data has shown promise in addressing how land-use pattern may influence population abundance, diversity, and resilience (Geoghegan et al. 1997). Work in the Patuxent region has correlated bird abundance and species diversity with land-use characteristics such as fragmentation (Flather and Sauer 1996). Others have shown how source population distance and natural corridors can influence recovery of both plants and animals following a catastrophic event (Hawkins et al. 1988, Detenbeck et al. 1992, Gustafson and Gardner 1996). We are calculating several spatial pattern indices using coastal plain watersheds and creating empirical models that link population characteristics to spatial pattern. These empirical models can be applied to the Patuxent watershed and, more importantly, to changes in the watershed as predicted by the PLM.

\footnotetext{
${ }^{12}$ URL: 〈http://iee.umces.edu/PLM $\rangle$
} 
Model development will continue with (1) a series of scaling experiments to better understand the tradeoffs between spatial, temporal, and complexity resolution and model performance; (2) addition of spatially explicit economic and social components to the unit model that will track built capital, human capital, and social capital; and (3) addition of spatially explicit animal population models for deer, beaver, and other "landscape structuring" species.

We also plan to continue software development to make spatially explicit landscape modeling more accessible. The Modular Modeling Language, which is under development (Maxwell and Costanza 1995), offers the promise that submodels or modules of varying degrees of detail can be developed independently and interchanged during model development. Then, as users implement a model for a particular area, modules can be selected based on the relative importance of local processes, and high detail can be used where needed but otherwise avoided (Voinov et al., unpublished manuscript). More work also remains to refine the model and address both data and model scaling issues.

We expect that these efforts will further advance our understanding of the often subtle and indirect links among and between the ecological and economic parts of regional landscape systems so that we may more wisely make the complex "place-based" decisions that we face.

\section{ACKNOWLEDGMENTS}

Initial funding for this research came from the U.S. EPA Office of Policy, Planning, and Evaluation (coop. agreement no. CR821925010, Michael Brody and Mary Jo Keely, project officers). Additional funding has been provided by the U.S. EPA/NSF Water and Watersheds Program through the U.S. EPA Office of Research and Development (grants no. R824766-010 and R82716901-1, Barbara Levinson and Brian Sidlauskas project officers; and the NSF Baltimore Ecosystem Study LTER, grant no. DEB-9714835, Steward Pickett, lead principal investigator). Our sincere thanks go to those researchers who shared their data and insights with us, including: Nancy Bockstael, Jacqueline Geoghegan, Elena Irwin, Kathleen Bell, Ivar Strand, Walter Boynton, Jim Hagy, Robert Gardner, Steve Kraemer, John Jones, Rich Hall, Debbie Weller, Joe Tassone, Joe Bachman, Randolph McFarland, Patricia Steinhilber, Tom Simpson, Frank Coale, Kent Mountford, Rob Magnien, Ron Klauda, Jim Vogelman, and many others at the Maryland Department of Natural Resources, Maryland Department of the Environment, and the University of Maryland Center for Environmental Science. Special thanks go to Carl Fitz for his major contributions to an earlier version of this model and continuing support. Thanks also to Frank Davis and two anonymous reviewers for their helpful comments on earlier drafts.

We would also like to credit the individual authors' contributions to this joint modeling exercise. R. Costanza directed the project, developed the initial ideas, and established the goals and objectives for the Patuxent landscape model, wrote most of the manuscript, and provided through various grants the funding necessary to accomplish the work. A. Voinov wrote parts of the manuscript, developed the hydrologic and nutrient modules, worked on the spatial implementation of the model, and performed spatial calibration and scenario runs. R. Boumans worked on the general ecosystem unit model and updated and calibrated the plant growth equations. T. Maxwell developed the spatial modeling environment (SME) software package and provided plug-ins and additions essential for the success of the PLM. F. Villa contributed to the SME software and developed procedures for model calibration. L. Wainger contributed to various early versions of the model and wrote and edited parts of earlier drafts of the manuscript. H. Voinov assembled and processed most of the data and provided essential GIS support.

\section{Literature Cited}

Abbott, M. B., J. C. Bathurst, J. A. Cunge, P. E. O'Connell, and J. Rasmussen. 1986. An introduction to the European Hydrological System-Systeme Hydrologique Europeen, "SHE" 2: structure of a physically-based, distributed modelling system." Journal of Hydrology 87:61-77.

Aber, J. D. 1992. Nitrogen cycling and nitrogen saturation in temperate forest ecosystems. Trends in Ecology and Evolution 7:220-224.

AQUA TERRA Consultants. 1994. Patuxent River Basin Watershed Model. U.S. Geological Survey, Towson, Maryland, USA.

Bandel, V. A., and E. A. Heger. 1994. MASCAP, Maryland's agronomic soil capability assessment program. Cooperative Extension Service, University of Maryland, College Park, Maryland, USA.

Beasley, D. B., and L. F. Huggins. 1980. ANSWERS (areal nonpoint source watershed environment response simulation), user's manual. Purdue University, West Lafayette, Indiana, USA.

Biggs, R. B. 1981. Freshwater inflow to estuaries, short and long-term perspectives. Pages 305-321 in R. D. Cross and D. L. Williams, editors. Proceedings of the National Symposium on Freshwater Inflow to Estuaries. Coastal Ecosystems Project, U.S. Fish and Wildlife Service. Washington, D.C., USA.

Bockstael, N. E. 1996. Economic and ecological modeling: the importance of a spatial perspective. American Journal of Agricultural Economics 78:1168-1180.

Bockstael, N., and K. Bell. 1998. Land use patterns and water quality: the effect of differential land management controls. Pages 169-191 in R. Just and S. Netanyahu, editors. International water and resource economics Consortium: conflict and cooperation on trans-boundary water resources. Kluwer, Norwell, Massachusetts, USA.

Bockstael, N., R. Costanza, I. Strand, W. Boynton, K. Bell, and L. Wainger. 1995. Ecological economic modeling and valuation of ecosystems. Ecological Economics 14:143159.

Boyer, M. C. 1964. Streamflow measurements. Pages 15.115.42 in V. T. Chow, editor. Handbook of applied hydrology. McGraw-Hill, New York, New York, USA.

Brush, G. S., and F. W. Davis. 1984. Stratigraphic evidence of human disturbance in an estuary. Quaternary Research 22:91-108.

Brush, G. S., C. Lenk, and J. Smith. 1980. The natural forests of Maryland: an explanation of the vegetation map of Maryland. Ecological Monographs 50:77-92.

Buchanan, J. T., W. Acevedo, and L. R. Richards. 1998. Preliminary assessment of land use change and its effects on the Chesapeake Bay. Moffett Field, U.S. Geological Survey, Ames Research Center. Poster.

Carpenter, S., W. Brock, and P. Hanson. 1999. Ecological and social dynamics in simple models of ecosystem management. Conservation Ecology 3:4. [Available from the Internet] URL: 〈http://www.consecol.org/vol3/iss2/art4〉

Cooper, S. R. 1995. Chesapeake Bay watershed historical land use impact on water quality and diatom communities. Ecological Applications 5:703-723.

Correll, D. L. 1983. N and P in soils and runoff of three 
coastal plain land uses. Chesapeake Bay Center for Environmental Studies Special Publication. No. 23. Smithsonian Institution, Washington, D.C., USA.

Correll, D. L., T. E. Jordan, and D. E. Weller. 1992. Nutrient flux in a landscape: effects of coastal land use and terrestrial community mosaic on nutrient transport to coastal waters. Estuaries 15:431-442.

Costanza, R., and T. Maxwell. 1994. Resolution and predictability: an approach to the scaling problem. Landscape Ecology 9:47-57.

Costanza, R., B. Norton, and B. J. Haskell, editors. 1992. Ecosystem health: new goals for environmental management. Island Press, Washington, D.C., USA.

Costanza, R., F. H. Sklar, and M. L. White. 1990. Modeling coastal landscape dynamics. BioScience 40:91-107.

Costanza, R., et al. 1997. The value of the world's ecosystem services and natural capital. Nature 387:253-260.

Costanza, R., et al. 1998. The value of the world's ecosystem services: putting the issues in perspective. Ecological Economics 25:67-72.

Creed, I. F., L. E. Band, N. W. Forster, I. K. Morrisson, J. A. Nicolson, R. S. Semkin, and D. S. Jeffries. 1996. Regulation of nitrate- $\mathrm{N}$ release from temperate forests: a test of the $\mathrm{N}$ flushing hypothesis. Water Resources Research 32: 3337-3354

Crum, J. R., F. J. Pierce, M. L. Vitosh, and B. D. Knezek. 1990. Potential nitrogen contamination of groundwater as affected by soil, water, and land use relationships. Technical Report No. 89-G1569-04. Michigan State University, Department of Crop and Soil Sciences, East Lansing, Michigan, USA.

Dale, V. H., S. Brown, R. A. Haeuber, N. T. Hobbs, N. Huntly, R. J. Naiman, W. E. Riebsame, M. G. Turner, and T. J. Valone. 2000. Ecological principles and guidelines for managing the use of land. Ecological Applications 10:639670.

Detenbeck, N. E., P. W. DeVore, G. J. Niemi, and A. Lima. 1992. Recovery of temperate-stream fish communities from disturbance: a review of case studies and synthesis of theory. Environmental Mangagement 16:33-53.

Donigian, A. S., J. C. Imhoff, B. R. Bicknell, and J. L. Kittle. 1984. Application guide for hydrological simulation program-FORTRAN (HSPF). Environmental Research Laboratory, Athens, Georgia, USA.

Fitz, H. C., R. Costanza, and E. Reyes. 1993. The Everglades landscape model (ELM): summary report of task 2, model development. Report to the South Florida Water Management District, Everglades Research Division, West Palm Beach, Florida, USA.

Fitz, H. C., E. DeBellevue, R. Costanza, R. Boumans, T. Maxwell, L. Wainger, and F. Sklar. 1996. Development of a general ecosystem model for a range of scales and ecosystems. Ecological Modeling 88:263-295.

Fitz, H. C., A. Voinov, and R. Costanza. 1995. The Everglades landscape model: calibration analysis report. Report to the Everglades Systems Research Division, South Florida Water Management District, West Palm Beach, Florida, USA.

Flather, C. H., and J. R. Sauer. 1996. Using landscape ecology to test hypotheses about large-scale abundance patterns in migratory birds. Ecology 77:28-35.

Gardner, R. H., M. S. Castro, R. P. Morgan, and S. W. Seagle. 1996. Nitrogen dynamics in forested lands of the Chesapeake Basin. STAC Perspectives on the Chesapeake Bay. No. 151. Chesapeake Research Consortium, Edgewater, Maryland, USA.

Geoghegan, J., L. Wainger, and N. Bockstael. 1997. Spatial landscape indices in a hedonic framework: an ecological economics analysis using GIS. Ecological Economics 23: $251-264$.
Gholz, H. L., S. Linder, and R. E. McMurtie. 1994. Environmental restraints on the structure and productivity of pine forest ecosystems: a comparative analysis. Munksgaard, Copenhagen, Denmark.

Gunderson, L. H., C. S. Holling, and S. Light, editors. 1995. Barriers and bridges to the renewal of ecosystems and institutions. Columbia University Press, New York, New York, USA.

Gustafson, E. J., and R. H. Gardner. 1996. The effect of landscape heterogeneity on the probability of patch colonization. Ecology 77:94-107.

Haith, D. A., L. J. Tubbs, and N. B. Pickering. 1984. Simulation of pollution by soil erosion and soil nutrient loss. Pudoc Press, Wageningen, the Netherlands.

Hawkins, C. P., L. J. Gottschalk, and S. S. Brown. 1988. Densities and habitat of tailed frog tadpoles in small streams near Mt. St. Helens following the 1980 eruption. Journal of the North American Benthological Society 7: 246-252.

Johnson, D. W., and S. E. Lindberg. 1992. Atmospheric deposition and forest nutrient cycling: a synthesis of the integrated forest study. Springer-Verlag, New York, New York, USA.

Kemp, W. M., W. R. Boynton, J. J. Cunningham, J. C. Stevenson, T. W. Jones, and J. C. Means. 1985. Effects of atrazine and linuron on photosynthesis and growth of the macrophytes, Potamogeton perfoliatus L. and Myriophyllum spicatum $\mathrm{L}$. in an estuarine environment. Marine Environmental Research 16:255-280.

Kemp, W. M., W. R. Boynton, R. R. Twilley, J. C. Stevenson, and J. C. Means. 1983. The decline of submerged vascular plants in Upper Chesapeake Bay: summary of results concerning possible causes. Marine Technology Society Journal 17:78-89.

Khan, H., and G. S. Brush. 1994. Nutrient and metal accumulation in a freshwater tidal marsh. Estuaries 17:345-360.

Kidwell, K. B. 1986. NOAA polar orbiter data user's guide. U.S. Department of Commerce, National Oceanographic and Aeronautics Administration/National Environmental Satellite, Data, and Information Service, Washington, D.C., USA.

Krysanova, V. P., D. Gerten, B. Klocking, and A. Becker. 1999. Factors affecting nitrogen export from diffuse sources: a modelling study in the Elbe basin. Pages 201212 in L. Heathwaite, editor. Impact of land-use change on nutrient loads from diffuse sources. International Association of Hydrological Sciences Publication no. 257.

Lichtenberg, E., and L. K. Shapiro. 1997. Agriculture and nitrate concentrations in Maryland community water system wells. Journal of Environmental Quality 26:145-153.

Lynch, J. A., and E. S. Corbett. 1990. Evaluation of best management practices for controlling nonpoint pollution from silviculture operations. Water Resources Bulletin 26: 41-52.

Magette, W. L., R. A. Weismiller, B. V. Lessley, J. D. Wood, and C. F. Miller. 1990. Demonstrating agricultural best management practice implementation and impacts on a commercial farm. ASAE-Applied Engineering in Agriculture 6:45-52.

Maryland Office of Planning. 1973. Natural Soil Groups of Maryland Technical Report. Maryland Department of State Planning. No. 199.

Maryland Office of Planning. 1993. Nonpoint source assessment and accounting system. Final report for fiscal year 1991, Section 319 Grant.

Maxwell, T., and R. Costanza. 1994. Spatial ecosystem modeling in a distributed computational environment. Pages 111-138 in J. van den Bergh and J. van der Straaten, editors. Toward sustainable development: concepts, methods, and policy. Island Press, Washington, D.C., USA. 
Maxwell, T., and R. Costanza. 1995. Distributed modular spatial ecosystem modelling. International Journal of Computer Simulation: Special Issue on Advanced Simulation Methodologies 5:247-262.

Novotny, V., and H. Olem. 1994. Water quality. Prevention, identification, and management of diffuse pollution. Van Nostrand Reinhold, New York, New York, USA.

O’Neill, R. V., C. T. Hunsaker, and D. A. Levine. 1992. Monitoring challenges and innovative ideas. Pages 1443-1460 in D. H. McKenzie, D. E. Hyatt, and V. J. McDonald, editors. Ecological indicators. Elsevier, London, UK.

Orth, R. J., J. F. Nowak, G. F. Anderson, D. J. Wilcox, J. R. Whiting, and L. S. Nagey. 1995. Distribution of submerged aquatic vegetation in the Chesapeake Bay and tributaries and Chincoteague Bay-1994. Final Report, U.S. Environmental Protection Agency, Washington, D.C., USA.

Parton, W. J., D. S. Ojima, D. S. Schimel, and T. G. F. Kittel. 1992. Development of simplified ecosystem models for applications in earth system studies: the CENTURY experience. Pages 281-302 in D. S. Ojima, editor. Modeling the earth system. Proceedings from the 1990 Global Change Institute on Earth System Modeling, 16-27 July 1990, Aspen Global Change Institute, Aspen, Colorado, USA.

Parton, W. J., J. W. B. Stewart, and C. V. Cole. 1988. Dynamics of $\mathrm{C}, \mathrm{N}, \mathrm{P}$, and $\mathrm{S}$ in grassland soils: a model. Biogeochemistry 5:109-131.

Peterjohn, W. T., and D. L. Correll. 1984. Nutrient dynamics in an agricultural watershed: observations on the role of a riparian forest. Ecology 65:1466-1475.

Rapport, D., R. Costanza, P. Epstein, C. Gaudet, and R. Levins. 1998. Ecosystem health. Blackwell Scientific, New York, New York, USA.

Reich, P. B., M. B. Walters, and D. S. Ellsworth. 1992. Leaf life-span in relation to leaf, plant, and stand characteristics among diverse ecosystems. Ecological Monographs 62: 365-392.
Running, S. W., and J. C. Coughlan. 1988. General model of forest ecosystem processes for regional applications, I. Hydrologic balance, canopy gas exchange and primary production processes. Ecological Modeling 42:125-154.

Sklar, F. H., and R. Costanza. 1991. The development of dynamic spatial models for landscape ecology: a review and prognosis. Pages $239-288$ in M. G. Turner and R. Gardner, editors. Quantitative methods in landscape ecology. Ecological studies 82. Springer-Verlag, New York, New York, USA.

Stevenson, F. J. 1986. Cycles of soil: carbon, nitrogen, phosphorus, sulfur, micronutrients. John Wiley and Sons, New York, New York, USA.

Turner, M. G. 1989. Landscape ecology: the effect of pattern on process. Annual Review of Ecology and Systematics 20:171-197.

U.S. Army Construction Engineering Research Laboratories, 1993. GRASS Version 4.1. User's reference manual. Open GRASS Foundation Center for Remote Sensing, Boston University, Boston, Massachusetts, USA.

Voinov, A., R. Costanza, L. Wainger, R. Boumans, F. Villa, T. Maxwell, and H. Voinov. 1999a. Patuxent landscape model: integrated ecological economic modeling of a watershed. Journal of Ecosystem Modelling and Software 14: 473-491.

Voinov, A., H. C. Fitz, and R. Costanza. 1998. Surface water flow in landscape models: an Everglades case study. Ecological Modeling 108:131-144.

Voinov, A., H. Voinov, and R. Costanza. 1999b. Surface water flow in landscape models: 2. Patuxent watershed case study. Ecological Modeling 119:211-221.

Vorosmarty, C. J., B. Moore, III, A. L. Grace, M. P. Gildea, J. M. Melillo, and B. J. Peterson. 1989. Continental scale model of water balance and fluvial transport: an application to South America. Global Biogeochemical Cycles 3:241265.

\section{APPENDIX}

The database for the Paxtuxent landscape model (PLM) is detailed in ESA's Electronic Data Archive: Ecological Archives M072-003-A1. 